\title{
Preliminary data on the exploitation of marine malacofauna by the Iberomaurusian groups of the Abri Alain rock shelter (Oran, Algeria)
}

Emilie Campmas, Amel Chakroun and Souhila Merzoug

\author{
(2) OpenEdition \\ Journals \\ Electronic version \\ URL: http://journals.openedition.org/paleo/3235 \\ DOI: $10.4000 /$ paleo.3235 \\ ISSN: $2101-0420$ \\ Publisher \\ SAMRA
}

\section{Printed version}

Date of publication: 30 December 2016

Number of pages: 83-104

ISSN: $1145-3370$

\section{Electronic reference}

Emilie Campmas, Amel Chakroun and Souhila Merzoug, "Preliminary data on the exploitation of marine malacofauna by the Iberomaurusian groups of the Abri Alain rock shelter (Oran, Algeria) », PALEO [Online], 27 | 2016, Online since 01 June 2018, connection on 07 July 2020. URL : http:// journals.openedition.org/paleo/3235; DOI : https://doi.org/10.4000/paleo.3235

This text was automatically generated on 7 July 2020 .

\section{c) (†)}

PALEO est mis à disposition selon les termes de la licence Creative Commons Attribution - Pas d'Utilisation Commerciale - Pas de Modification 4.0 International 


\title{
Preliminary data on the exploitation of marine malacofauna by the Iberomaurusian groups of the Abri Alain rock shelter (Oran, Algeria)
}

\author{
Emilie Campmas, Amel Chakroun and Souhila Merzoug
}

We express our gratitude to H. De Lumley, St. and R. Orliac for giving us access to the collections of the Institut de Paléontologie Humaine. Sincere thanks also to C. Daujeard and L. Crépin, for their revision, feedback and access to the stereomicroscope at the IPH (C. Daujeard). We thank E. Stoetzel for communicating her unpublished data from the microfauna anaysis, as well as for her revision and comments. Thanks to S. Chibane for discussions about the Iberomaurusien and the exploitation of the terrestrial vertebrates from Abri Alain. We thank in particular P. Granchon (INRAP) for passing on the dissertation and L. Sari for help. All our gratitude also to M. Cammas for the graphics in figure 1. We thank the two reviewers, M. Nami and the second anonymous reviewer for their comments and sound advice.

\section{Introduction}

1 Research on the Iberomaurusian has significantly increased in recent years. This culture, which corresponds to the Upper Palaeolithic / Later Stone Age in North Africa, is dated between about 22 and $9.5 \mathrm{ka}$ cal BP (e.g., Barton et al. 2007, 2008, 2013, 2016; Bouzouggar et al. 2008; Linstädter 2008; Linstädter et al. 2012; Hogue and Barton 2016). The lithic industries, characterized by the presence of bladelets and microliths (Balout 1950; Tixier 1963; Camps 1974; Bouzouggar et al. 2008; Linstädter et al. 2012; Sari 2008, 2012, 2014; Stoetzel et al. 2014; Hogue and Barton 2016), seem to evolve during the course of time (e.g. Moser 2003; Barton et al. 2013). Recent researches combining paleoenvironmental, chronological and cultural data suggest that the Iberomaurusian could be split into two main early and recent phases, represented in the stratigraphies by a transition from yellow deposits to powdery black deposits with abundant shells 
and molluscs. According to the publications, this transition may have taken place around $16 \mathrm{ka}$ cal BP at Ifri n'Ammar (Moser 2003), or $15 \mathrm{ka}$ cal BP at Taforalt (Barton et al. 2013). The available data for these two phases do not seem to be comparable, as the recent phase is better documented (Linstädter 2008). For this phase, the example of Taforalt (Morocco) shows the presence of cemeteries, where funerary practices appear to be complex (post-mortem treatment of the corpses, association with offerings, particularly horns from slaughtered Barbary sheep....) (Mariotti et al. 2009; Mariotti, Condemi, Belcastro 2014, 2016; Humphrey et al. 2012; Aoudia-Chouarki 2013). These populations practised the avulsion of the upper incisors (Hadjouis 2002; Barton et al. 2008; Aoudia-Chouarki 2013; Humphrey and Bocaege, 2008; De Groote and Humphrey 2015), and show dental pathologies (caries) pointing to poor sanitary conditions (Poitrat-Targowla 1977; Humphrey et al. 2014). L. Humphrey et al. (2014) suggest that these dental afflictions could result from the consumption of wild plants with a high content of fermentable carbohydrates, which seems to be confirmed by the carpological analyses, which identified debris from holm oak acorns and pine nuts. In this way, this recent phase, which seems to be linked to wetter climatic conditions, is associated with major behavioural changes (diversification of the exploited resources, increase in sedentariness, introduction of cemeteries, etc.) (Barton et al. 2013).

However, data on the subsistence of these groups are still scant. Work carried out in Algeria on vertebrate fauna by S. Merzoug $(2005,2008)$, S. Merzoug and L. Sari (2008) and S. Chibane (2016) suggests that Iberomaurusian populations mainly consumed ungulates from the environment around the sites (Barbary sheep in steep zones or hartebeest in plains), along with a lower proportion of other diverse taxa (lagomorphs, birds, etc.) (Merzoug 2005; Chibane 2016). As well as the vertebrate fauna, terrestrial malacofauna seems to represent a considerable portion of the exploited resources (Taylor et al. 2011). Although many Iberomaurusian sites are located in coastal zones, data on the exploitation of the marine environment, and particularly marine molluscs, remain rare, whereas they may have been eaten or used for making ornaments (Camps 1974; Sidi Maamar 1987; Camps-Fabrer 1994).

In this article, we will present the first elements of the preliminary review of the marine malacofauna from the Iberomaurusian levels of Abri Alain, excavated at the beginning of the $20^{\text {th }}$ century by P. Pallary and curated at the Institut de Paléontologie Humaine (IPH) in Paris.

The aims of this work focusing on the marine malacofauna are:

- to identify the species exploited by humans during the Iberomaurusian;

- to assess whether they were used for food purposes or non-food purposes;

- to provide data on acquisition zones and strategies as well as on processing methods;

- to evaluate the informative potential of ancient malacological collections.

\section{1 - Abri Alain}

Abri Alain is located in the Oran region (northwest of Algeria), currently situated $5 \mathrm{~km}$ from the Mediterranean, north of the Sebkha of Oran and at an altitude of $100 \mathrm{~m}$ in a ravine on the slopes of Djebel Murdjadjo (fig. 1) (Pallary 1934). The location of this site enables us to assess the question of the role of marine resources for Iberomaurusian groups. 
Figure 1 - Location of Alain rock shelter.

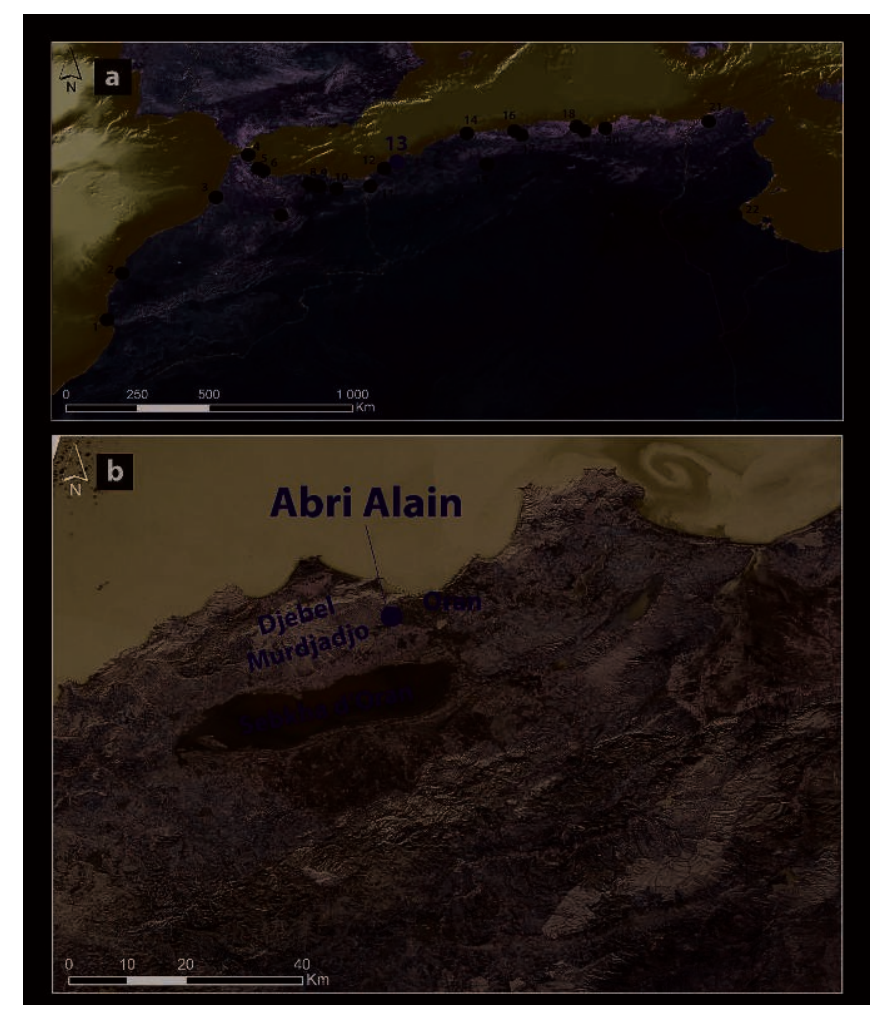

a) among the main Iberomaurusian sites [1. Cap Rhir, 2. El Khenzira, 3. Témara, 4. Ghar Cahal, 5. Kehf El Hammar, 6. Hattab II, 7. Kifan Bel Ghomari, 8. Ifri El Baroud, 9. Ifri n'Ammar, 10. Taforalt, 11. La Mouillah, 12. Rachgoun, 13. Abri Alain, 14. Cap Ténes, 15. Columnata, 16. Rolland, 17. Rassel, 18. Afalou Bou Rhummel, 19. Tamar Hat, 20. Taza, 21. Ouchata; 22. Oued-Akarit (adapted from Barton et al. 2013)]; b) in the Oran region.

(CAD: M. Cammas and E. Campmas)

6 Abri Alain was discovered by P. Pallary in 1906, who excavated different loci from 1927 to 1930 (Pallary 1934). Note that F. Doumergue, who rediscovered this site in 1914 and excavated it in 1916, called the site the "cave of the Eckmühl quarries" (Doumergue 1935). This rock shelter (or dismantled cave) is carved into quarried Upper Miocene white limestone (Sahelian stage) (Pallary 1934).

During his excavations, P. Pallary (1934) described a stratigraphy with four layers, from the deepest to the uppermost layer:

- "Yellow layer": $50 \mathrm{~cm}$ thick, chrome yellow colour, compact, sandy, with scant archaeological material and snails (mainly Rumina);

- "Brown-yellow layer": with abundant faunal remains, powdery, sandy, then rich in snails (mainly Archelix and Rumina) and archaeological material, it also contains ornamental elements (scallops and tusk shells);

- "Black layer": powdery, abundant snail shells, marine mollusc shells (powdery, sandy, then rich in snails (limpets, mussels, monodontes), as well as scallops and tusk shells.

- "Chocolate brown layer": very hard, rich in pebbles and stones, presence of snails and vertebrates, several marine mollusc shells.

8 However, in the IPH, only two "yellow" and "black" layers are referenced, like on some of P. Pallary's stratigraphic sections (1934) (fig. 2). 
Figure 2 - a) Schematic stratigraphic section of Alain rock shelter, November 16th, 1927 (from Pallary 1934); b) Photograph of the section, February 25th, 1928.

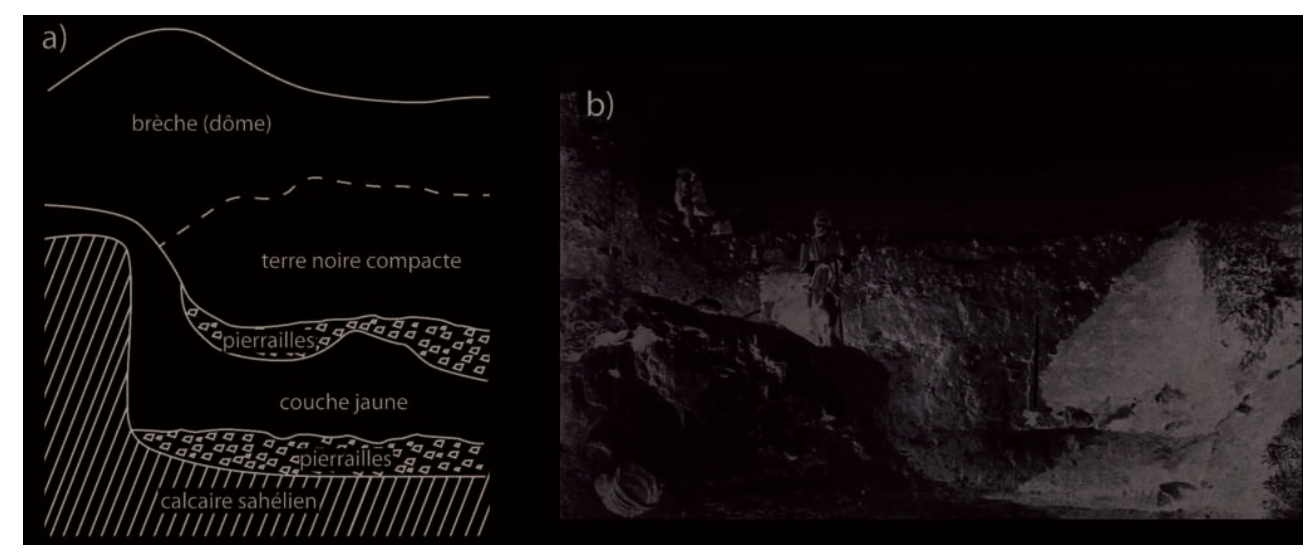

(Photo G. Buoän in P. Pallary 1934 - PI. 11)

9 According to H. Hellal (2005), two charcoal samples from the "black layer" were dated by the Centre Scientifique de Monaco in 1975. They gave ages of $12550 \pm 190 \mathrm{BP}$ and $12660 \pm 200$ BP (Hellal 2005), or between 15700 and 14100 cal BP (fig. 3).

Figure 3 - Modelled ages of the black layer of Alain rock shelter.

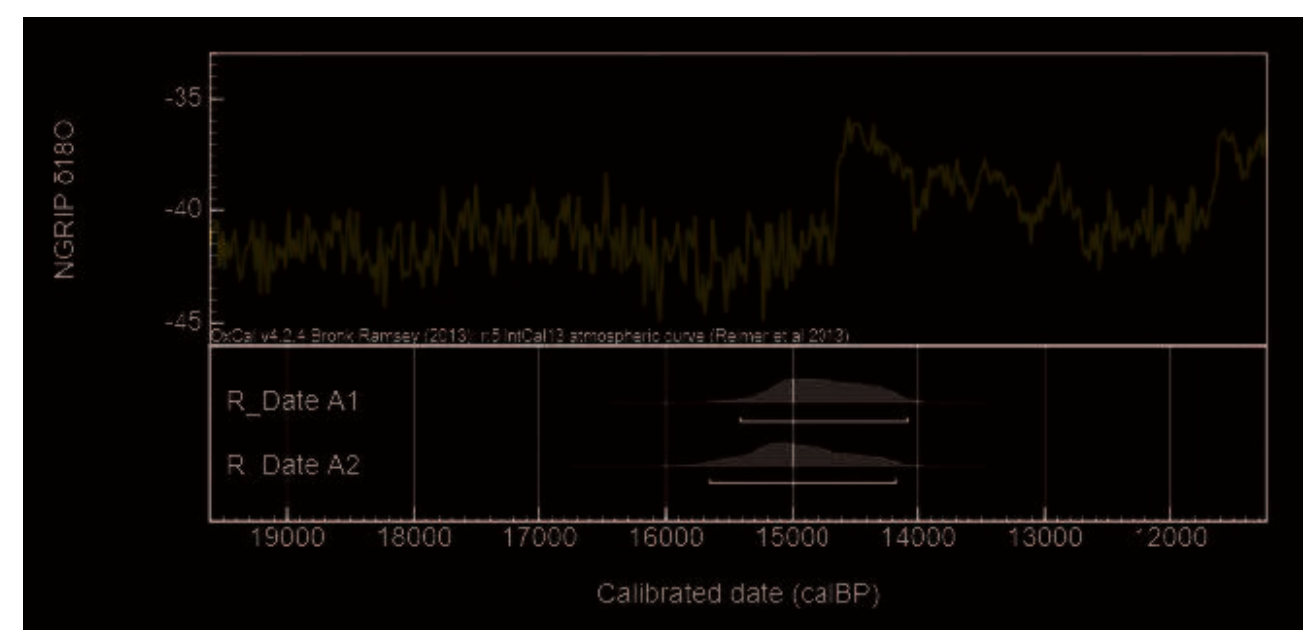

The lithic material curated at the IPH underwent two studies of the "yellow layer" and the "black layer", by P. Granchon (1987) and H. Hellal (2005) respectively. P. Granchon (1987) described an Iberomaurusian industry mainly made up of backed bladelets, more rarely with other tools such as end scrapers and burins. H. Hellal (2005) indicates that the industry is characterized by accentuated microlithism. The black layer also consists mainly of backed bladelets associated with rare elements, such as end scrapers and side scrapers or even geometric microliths. Note that although F. Doumergue (1935) attributed the industry from the black deposit to the Iberomaurusian, based on the lithic characteristics and the absence of pottery, he also observed similarities with the Neolithic deposits from other Algerian sites and he emitted reservations as to the attribution of the upper part of this black level.

11 The paleontological analysis of the "yellow" layer (Abbar 2014) and the archaeozoological study of the "black" and "yellow" layers (Chibane 2016) suggest that 
the main vertebrate fauna exploited by humans are the Barbary sheep and the hartebeest, along with less frequent taxa, such as gazelles, birds or leporids.

The preliminary analysis of the microfauna from these two layers (observations made by E. Stoetzel) showed that few remains were present $(<130)$, including the tortoise (Testudo graeca), indeterminate birds, hedgehogs (cf. Atelerix algirus) and Gerbillinae rodents (Meriones cf. shawii, Psammomys sp.), which could indicate semi-arid to arid environments. The genus Psammomys is not currently found in arid pre-Saharan zones. P. Pallary (1934) mentions the remains of lizards and chiropters, but they were not observed by E. Stoetzel during the revision of the material. The smallest species (gerbils, mice, shrews) are absent, probably on account of the sampling method used (coarse sieving with a $4 \mathrm{~mm}$ mesh according to Pallary 1934).

13 A first malacological analysis of these two layers by H. Sidi Maamar (1987) shows that marine and terrestrial molluscs are present at Abri Alain, some of which were eaten (marine and terrestrial), and some of which were used as ornaments (marine).

\section{2 - Material, integrity of the assemblages and method}

\section{1 - Material}

We studied 1426 marine mollusc remains (tabl. 1) curated at the IPH. According to the indications associated with the material, these elements seem to come from the "yellow" and "black" layers. Nonetheless, not all the remains are systematically associated with indications of the stratigraphic provenance, and no precise information concerning the spatial location (plan, excavation locus, coordinates) and their provenance was found for the P. Pallary excavations (1934).

\section{2 - Integrity of the assemblages}

15 The material at the IPH is attributed to two ("yellow" and "black") layers, but P. Pallary (1934) mentions four layers in his stratigraphic description. In addition, the presence of potentially consumed marine mollusc shells in boxes with "yellow layer" labels is intriguing, as P. Pallary (1934) specified that "the second [which were used as food] are only exclusively found in the very upper part of the black layer" (Pallary 1934 - p. 26) and he effectively indicates the presence of "Limpets, Mussels, Monodontes" in the "black layer" (Pallary 1934 - p. 19). Moreover, in the malacological description, P. Pallary states that "the former [which were used as ornamental elements] are spread out over the whole thickness of the deposit" (Pallary 1934 - p. 26), or that "we see comestible marine molluscs (Mussels, Limpets, Murex, Periwinkles) appear in the upper part of the deposit, and no longer only ornamental shells, like there are so many of in the yellow and black deposit" (Pallary 1934 - p. 21), whereas in his stratigraphic description, he only indicates their presence in the mid "brown-yellow" and "black" layers, and does not mention them in the "lower yellow" layer (Pallary 1934 - p. 19).

However, during his study, H. Sidi Maamar (1987), who conserved the division of the malacofauna into "black layer" and "yellow layer", describes ornamental elements in these two levels. The analyses of the microfauna (observation by E. Stoetzel) and the macrofauna (Chibane 2016), do not identify any taphonomic or taxonomic difference between the "yellow" and "black" levels. In addition, black concretions are present on 
the malacofauna analysed by H. Sidi Maamar (1987) alleged to come from the "yellow" layer. For the conservation of the collections, the material was not washed during the course of this preliminary analysis, which limited the observation of the surfaces. It is important to note here that the sediment present on the shells from the "black" and "yellow" layers is mainly black. Therefore, considering the complex history of this collection and the probable mixing that it underwent, the results given here are the results of the analysis of the whole series of marine molluscs, which we consider to come mainly from the black layer, or even from the underlying "mid brown-yellow layer". If inter-layer refits are found in the future, they may confirm this hypothesis. In addition, the collection curated at the IPH only seems to correspond to part of the excavated remains. In fact, P. Granchon (1987 - p. 31) points out that it is unlikely that the material from the last excavation year, 1930, is included in the IPH collections. Sieving with a $4 \mathrm{~mm}$ mesh was carried out during that year (Pallary 1934), which seems to be confirmed by the analysis of the lithic material, which includes abundant cores and flakes (Granchon 1987). Nonetheless, the archaeozoological analysis (Chibane 2016) highlights the under-representation of small bone shards, as well as long bone shafts, which are generally the predominant portions in anthropogenic sites. The rarity of the microfauna also points to sieving with a large mesh. It thus seems as though smallsized fragments are absent and that there may have been a differential selection of the remains at the excavation.

Thus, although the sample conserved at the IPH probably only represents a portion of the marine malacofauna present at Abri Alain, it nonetheless enables us to provide new data on its use by Iberomaurusian groups.

\section{3 - Methodology}

The determination of the marine malacofauna was based on classical works on Mediterranean malacology (e.g. Bucquoy, Dautzenberg, Dollfus 1882-1886, 1887-1889; Sacco 1890-1904; Locard 1892; Perrier 1954). In specific cases related in particular to the determination of limpets, the personal collection of M. Feki (Department of Geology of the Science University in Tunis), as well as the collection of the Muséum National d'Histoire Naturelle - Inventaire National du Patrimoine Naturel (https:// inpn.mnhn.fr) were consulted.

The determination of the different species of molluscs and their paleoecological environments was also based on the current species referenced in Algeria (Méziane and Kerfouf 2013), as well as on the malacological and paleoenvironmental data from the Upper Pleistocene in Tunisia and the Mediterranean Basin (Chakroun 2006; Chakroun et al. 2009; Chakroun and Zaghbib Turki, in press). Unfortunately, the sedimentary deposits covering the internal and external surfaces of the shells limited observation and the descriptive terminology. Our observations were compared to the former data of P. Pallary (1934) and H. Sidi Maamar (1987). However, we did not re-examine the objects photographed by H. Sidi Maamar (1987). The nomenclatures used by the different authors were updated using the database: World Register of Marine Species (http://www.marinespecies.org).

The quantification by family was carried out using the method developed by C. Dupont (2006). In this way, we counted the Number of Remains (NR) belonging to marine shells, as well as the Minimum Number of Individuals (MNI). For the gastropods, such as the 
Patellidae, Trochidae, Turritellidae, we counted the MNI using the apex. For the bivalves, we used the zones with the hook. Nonetheless, although for the Mytilidae we could differentiate right and left valves, for the other bivalves, we counted the number of zones with hooks and divided them by two. For the scaphopods such as the Dentaliidae, with an elongated more or less curved (ventral concavity and dorsal convexity) conical shell open at both ends, we used the zone with a curve. As this collection probably comes from a selective collection during excavations, we assessed the state of degradation of the shells using the classification established by Dupont (2006), without quantifying it. On the other hand, no biometric evaluation was carried out, which limits discussions regarding the selection of specimens based on size.

Although the shells were not washed, we made preliminary observations of the surface (low magnification $\mathrm{x} 10$ ) in order to identify any possible natural or anthropogenic modifications. A sample of 28 shells from different species was also observed with a stereomicroscope at higher magnifications (Stereomicroscope Leica S8 APO, magnification10-80x).

\section{3 - Results}

\section{1 - Spectrum}

The malacological spectrum includes many taxa (tab. 1).

Table 1 - Malacofaunal spectrum (NR and MNI) by broad taxonomic classes (J?-artefact appears to be associated with a non-original label).

\begin{tabular}{|c|c|c|c|c|}
\hline & NR & NMI & \begin{tabular}{|} 
Présence dans \\
les couches \\
" noire " (N) et \\
" jaune" ( $(\mathrm{J})$ de \\
I'IPH d'après \\
les cartels \\
associés au \\
matériel
\end{tabular} & $\begin{array}{c}\text { Attribution } \\
\text { couches } \\
\text { " jaune \# (J) et } \\
\text { " noire » selon } \\
\text { H. Sidi Maamar } \\
\text { (1987). }\end{array}$ \\
\hline Dentaliidae & 557 & $\sim 270$ & $\mathrm{~J}-\mathrm{N}$ & \\
\hline $\begin{array}{l}\text { Glycymerididae cf. } \\
\text { Glycymeris nummaria }\end{array}$ & 408 & 109 & $\mathrm{J-N}$ & $\mathrm{N}$ \\
\hline $\begin{array}{l}\text { Glycymerididae cf. } \\
\text { Glycymeris pilosa }\end{array}$ & 12 & 6 & N & $\mathrm{N}$ \\
\hline Patellidae & 205 & 140 & $\sqrt{3 ?-N}$ & $\mathrm{~J}-\mathrm{N}$ \\
\hline Mytilidae & 153 & 25 & $\sqrt{3 ?-\mathrm{N}}$ & $\mathrm{J-N}$ \\
\hline Trochidae & 31 & 12 & $\sqrt{3 ?-\mathrm{N}}$ & $J$ \\
\hline Turritellidae & 21 & 11 & $e$ & $\sqrt{J}$ \\
\hline Cardiidae & 16 & 4 & $N$ & $\mathrm{~N}$ \\
\hline Muricidae & 2 & 1 & $N$ & $\sqrt{N}$ \\
\hline Ostreidae & $\overline{2}$ & 1 & $N$ & $\mathrm{~N}$ \\
\hline Pectinidae & 1 & 1 & J? & $\mathrm{N}$ \\
\hline $\begin{array}{l}\text { Empreinte fossile de } \\
\text { bivalves }\end{array}$ & 17 & & & \\
\hline Serpulidae isolés & 1 & 1 & & \\
\hline Total & 1426 & $\sim 581$ & & \\
\hline Consommés & 391 & 178 & & \\
\hline $\begin{array}{l}\text { Non alimentaires } \\
\text { (ornement) }\end{array}$ & 999 & 397 & & \\
\hline Fonction indet. & 18 & 5 & & \\
\hline
\end{tabular}

For the Patellidae, the sediment still present on the surface of the shells limited their identification. However, we were able to re-observe the species described by Pallary 
(1934). We mainly identified Patella ferruginea and Patella caerulea. Patella ferruginea is generally large in size (50-70 $\mathrm{mm}$ ), and was easily identifiable, even in its fragmentary state, on account of the strong and marked ribs (Perrier 1954). We recognized Patella caerulea by the shape of the robust, rather flattened, conical shaped shell, with a slightly anterior summit and a rounded denticulated base, with an external surface made up of many radiating, uneven, slightly undulating furrows and fine concentric growth striations (Bucquoy et al. 1882-1886; Rampal 1965). Among the different specimens of Patella caerulea, we distinguished the typical Patella caerulea form and the subplana variety, described by Potiez and Michaud (1838). The shell of the latter is pentagonal with radiating bulging ribs and radiating furrows. The peristome is rounded, cutting, irregularly fluted and denticulated, with abundant growth striations close together, giving the surface a slightly rough aspect (fig. $5 c, b)$. These observations correspond perfectly to the diagnosis of D.E. Bucquoy et al. (1882-1886) and J. Rampal (1965). We also identified another specimen with affinities with Patella caerulea variety subplana mutation stellata (Bucquoy et al. 1882-1886; Rampal 1965). It can be differentiated by its radiating ribs that extend into angular prolongations, giving the shell a starry aspect (fig. 5a). However, today, all these forms are grouped under the appellation Patella caerulea. In addition, one specimen (in fragmentary condition) could also belong to Patella rustica which stands out on account of its grainy surface, dotted with black marks, and the fact that it is generally higher than Patella caerulea (Bucquoy et al. 1882-1886). Note that H. Sidi Maamar (1987) identified the species Patella aspera, which had not been identified by P. Pallary (1934) or in the IPH collection that we observed. Patella aspera is characterized by a conical shell with an oval denticulated base with slight anterior narrowing, with a slightly off-line summit towards the front. It is also adorned with abundant uneven and rough radiating ribs cut by concentric growth striations which identify spiny roughness (Bucquoy et al. 1882-1886; Rampal 1965). In our case, the sediment covering the shells limits the identification of the necessary morphological characteristics for the distinction between Patella caerulea and Patella aspera, which, in addition, according to G. Sella, Robotti, Biglione (1993), have similar morphologies and colouring, which sometimes makes them difficult to distinguish.

Among the Trochidae, we identified Phorcus turbinatus, which is easily distinguishable on account of its rounded aperture, its thick and solid slightly elevated shell, made up of six convex whorls, the last of which is rounded, with a slightly callous umbilical region (Bucquoy et al. 1882-1886; Locard 1892). Some of the observed specimens still present grey colour pigmentation marked by reddish, sometimes purplish, subquadrangular and elongated stains (fig. 5l).

We also observed rare fragments of Stramonita haemastoma shells, a widespread gastropod in Upper Pleistocene Mediterranean deposits (Chakroun, Zaghbib-Turki, Moncef-Turki 2016; Chakroun and Zaghbib-Turki in press). This rather large-sized species $(50-60 \mathrm{~mm})$ is adorned with tubers and characterized by a last developed whorl and a wide aperture (Perrier 1954). The Turritellidae belong to the Turritella triplicata species, which is a gastropod with a shell with a rounded aperture and many turns, giving it an elongated shape (Hörnes 1852-1856; Esu and Girotti 2010). The Scaphopod shells are abundant and correspond taxonomically mainly to the Dentaliidae family. The fragments that we identified seem to belong to three common 
Mediterranean species, described by P. Pallary (1934): Antalis vulgaris, Antalis inaequicostata and Fustaria rubescens.

The Cardiidae are represented by Cerastoderma edule with a shell characterized by marked radiating ribs, crossed by clearly visible growth striations with no spines or bulging tubers (Bucquoy et al. 1987-1998) and Acanthocardia tuberculata, which has a thick shell with marked, robust and radiating ribs presenting short, sometimes nodulous or absent spines, (Perrier 1954).

The observed Glycymerididae shells are eroded. The erosion on the external surface is visible as erosion of the ribs and on the internal surface by the wear of the teeth of the cardinal plateau and the crenulations on the ventral edge of the shells. Consequently, specific determination is extremely difficult. However, two species seem to be present: Glycymeris pilosa and Glycymeris nummaria according to P. Pallary (1934).

Among the Pectenidae, H. Sidi Maamar (1987) distinguished the species Pecten maximus. However, the fragments that he presented seem to correspond to the dorsal valve of Pecten jacobaeus, which is in keeping with the diagnosis of M. Feki (1975) (relatively strong convexity of the valve and rounded section of the ribs).

31 As for the Ostreidae, P. Pallary (1934) identified Ostrea edulis. H. Sidi Maamar (1987) indicates the presence of Crassostrea angulata, but there may be confusion with Ostrea edulis, which he considers to be a synonym, as Crassostrea angulata was imported to Europe from Asia in the $19^{\text {th }}$ century (Huvet 2000; Pascal, Clergeau, Lorvelec 2010). The shells of the different tubiform species are extremely difficult to determine. The latter correspond either to annelids of the Serpulidae family or to molluscs of the Vermetidae family.

P. Pallary (1934) and H. Sidi Maamar (1987) also mentioned the presence of Ranellidae (Charonia lampa) and Cerithiidae (Cerithium vulgatum). We did not re-observe these taxa, but they seem to be common in North African Quaternary marine fauna associations (Chakroun 2006; Chakroun et al. 2009; Chakroun, Zaghbib-Turki, Moncef-Turki 2016).

We also note the presence of fish vertebrae and fragments of sea urchin tests. A fossil tooth, which could belong to a megalodon (fig. 4c), had already been identified by $\mathrm{P}$. Pallary (1934). Fossil mollusc shell imprints (fig. a,b) are also present. The latter probably come from the surrounding Upper Miocene (Sahelian) white bedrock with marine fauna, intercalated with marls with abundant fish remains and mollusc shells (Gentil 1903; Roger 1942; Freneix, Saint-Martin, Moissette 1987) or similar deposits, as the Sahelian marls with flint from Djebel Murdjadjo contain abundant fossil fish remains, particularly Carcharodon megalodon (Arambourg 1927). 
Figure 4 - a-b) Fossil shell impressions; c) megalodon tooth; d) sea urchin shell.

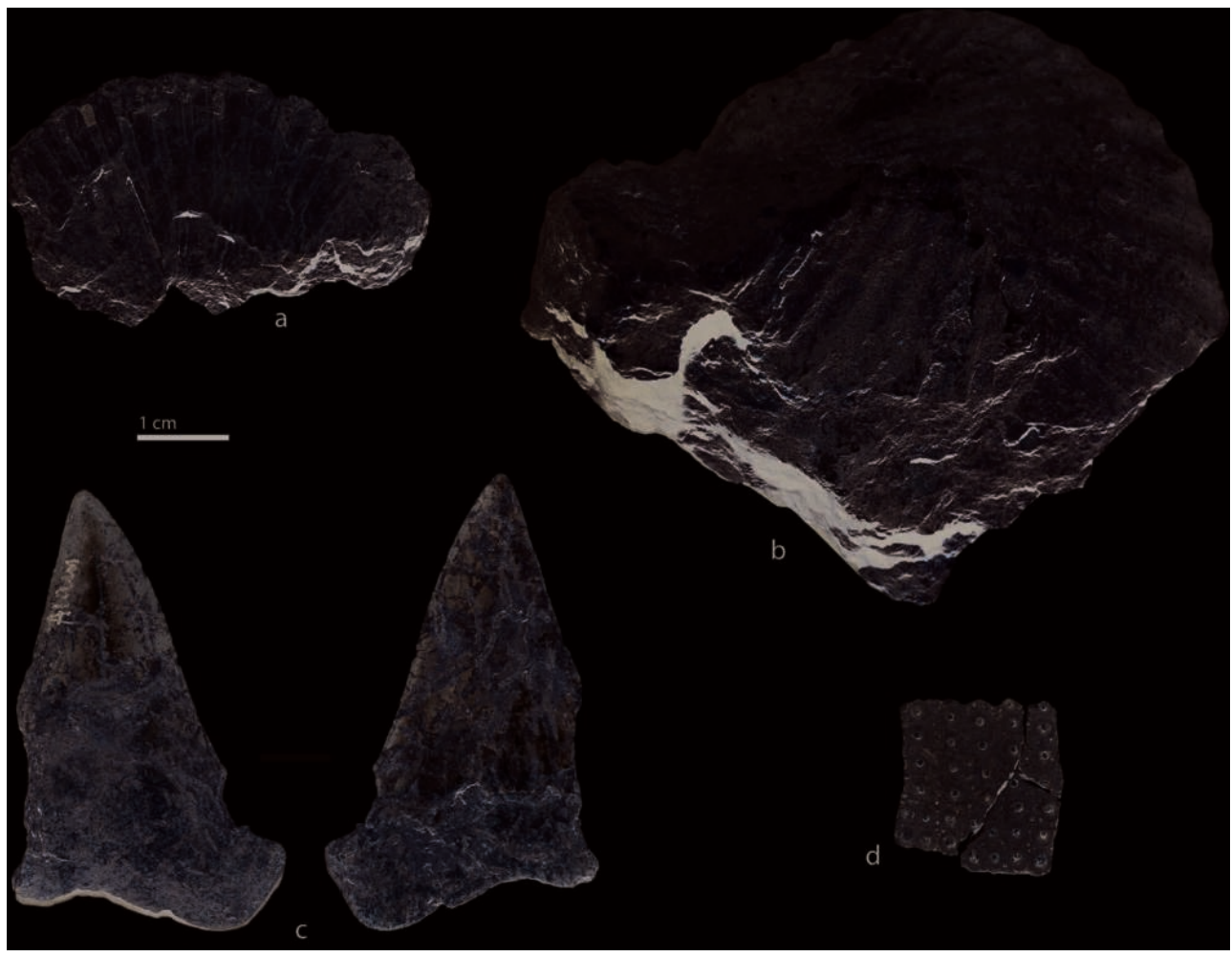

(Photos E. Campmas)

\section{2 - Which species were consumed?}

The macroscopic observation of the surfaces of the rare cleaned limpets suggests that they were not exposed on the beach for long before being collected (fig. 5a). The same seems to apply to the Mytilidae. Some limpet shells present notches (fig. $5 b$ ) similar to those left by knife blades between the shell and the rock for a lever effect during present-day collection (fig. $5 \mathrm{c}$ or Nouet et al. 2015). Other shells show major fragmentation, at different stages of deterioration following the typology proposed by C. Dupont (2006) (fig. 5d-f). As limpet shells tend to break along preferential zones of fragility, corresponding to circular growth lines (e.g., Dupont 2006), the observed fragmentation may be associated with a post-depositional taphonomic process such as trampling or sediment compaction. A whole mussel valve also bears a notch in a relatively non-fragile zone of the shell (fig. $5 \mathrm{~h}$ ). This notch is also similar to those currently produced when mussels are opened on the Mediterranean coast by the mollusc merchants at the Port of Grau de Vendres (Hérault) in order to eat them raw (personal observation E. Campmas) (fig. 5i-j). The absence of the apex on some Trochidae shells (fig. 5l) could be explained by the removal of this part to facilitate the extraction of the flesh (Russell et al. 1995; Bosch et al. 2015). The most fragile zones, the preferential fragmentation zones of Trochidae, correspond to the sutures of the whorl turns (e.g. Dupont 2006).

36 For the Patellidae, Mytilidae and Trochidae shells, the absence of traces of bioerosion by lithophagia, as well as the mechanical erosion linked to the backlash of the waves, imply that these molluscs were collected alive. Traces compatible with collection or 
intentional extraction (notches on the Patellidae and Mytilidae shells and absence of the apex zone on Trochidae shells) could confirm the collection of fresh molluscs in order to eat them. Given their fragmentary state and the very low number of remains identified for Muricidae (fig. 5m), Ostreidae, Cardiidae (Cerastoderma edule), and even Pectenidae, their contribution to the diet can neither be rejected or confirmed. The tubiform species were probably brought back unintentionally (fig. 5n), on the shells of other species (fig. 5h).

Pectenidae and Cerastoderma edule live in the infratidal zone, sometimes buried in the sandy substratum, but their contribution to the diet is uncertain. The consumed molluscs (Mytilidae, Patellidae, Trochidae) are found in a rocky biotope in the intertidal zone, where they were probably collected at low tide. Depending on their sensitivity to desiccation, the different species of Patellidae do not live in the same parts of the intertidal zone. Patella ferruginea is found in the upper part of the intertidal zone, while Patella caerulea and Patella aspera are dependent on the lower part of the medio-littoral and infralittoral zone, in permanently wet zones, although Patella aspera can be found in slightly deeper zones than Patella caerulea. The main distribution difference between these two latter species is linked to the variability of exposure to waves. Indeed, Patella aspera seems to be found on rocky substrata exposed to strong wave action, unlike Patella caerulea (Rampal 1965; Sella et al. 1993). Thus, bearing in mind the difficulty in differentiating between Patella caerulea and Patella aspera, particularly for this noncleaned collection, we can emit the hypothesis that even if the Iberomaurusian huntergatherers from Abri Alain seem to have exploited all the foreshore levels, a real absence of Patella aspera, which lives in deep and agitated environments, could indicate that human groups avoided zones that could be dangerous.

Although Mytilidae live in aggregates and can be collected in mass by sectioning the byssal thread, Patellidae, which are more difficult to detach from the rocky substratum, must be collected one by one (e.g. Fa 2008). The notches on the Patellidae shells could point to their gathering with an adapted tool, for example a flat tool sliding between the shell and the rock. Limpets can be collected without tools, for example at night when they eat or by simple percussion, with a pebble (e.g. Russell, Bonsall, Sutherland 1995). Mytilidae are represented by specimens of different sizes, including several small specimens (juveniles), (fig. 5g), showing that no selection of large specimens was applied to gathering. Indeed, even in cases when large mussels are sought out, the mass collection of mussels can result in the gathering of different categories of shell sizes, which can be sorted after collection (personal observation by E. Campmas as part of the ACoAPass project - TRACES seed funds).

39 As for processing methods, the heating of mussels can open them and leaves no traces if a container is used, unlike direct cooking without a container on or under the embers (e.g. Aldeias et al. 2016). Only an attentive study of the state of the shell surfaces and physico-chemical analyses (FTIR) could provide an answer to these considerations. The notch observed on one of the mussel shells indicates that they were eaten raw, in the same way as the removal of the apex for Trochidae.

In addition to eating molluscs, the human groups must also have consumed sea urchins (presence of tests) (fig. 4d) and maybe fish (presence of vertebrae and mandibles) (Chibane 2016). 
Figure 5 - Consumed and accidentally introduced molluscs at Alain rock shelter and comparison with modern observations.

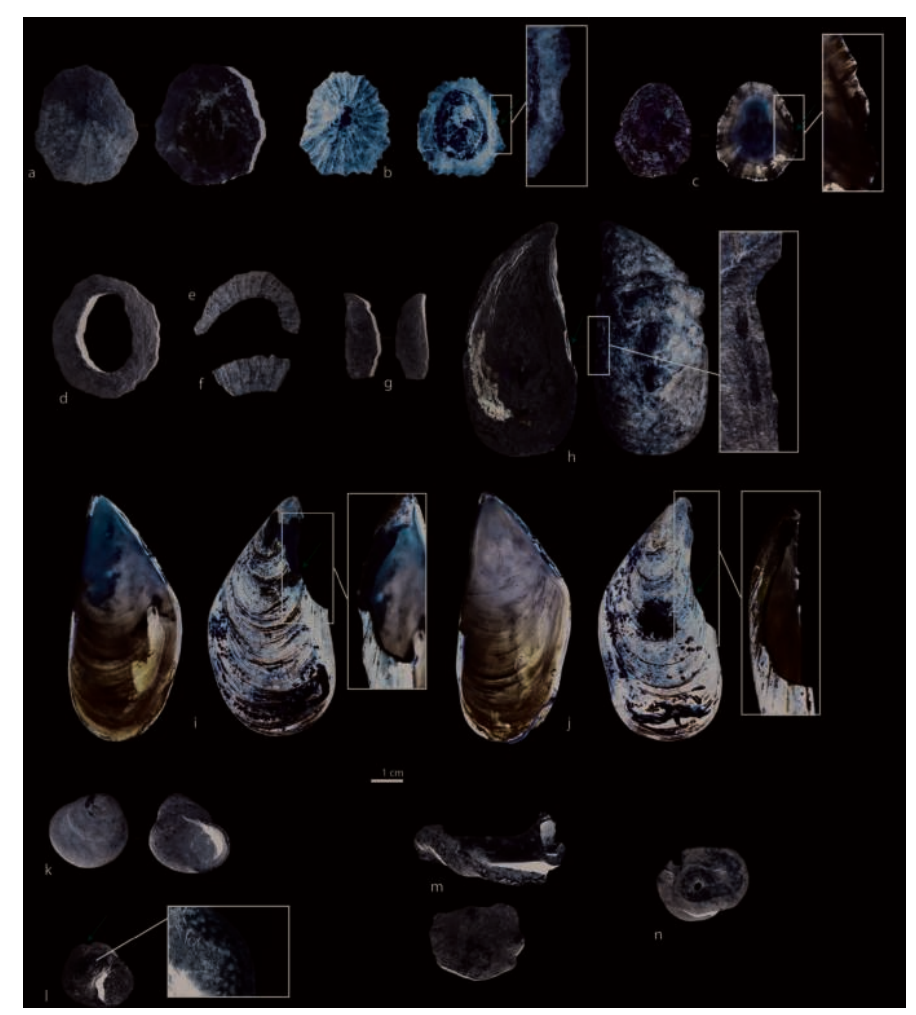

a-f) Patellidae [a-b, d-f) Patellidae from Alain rock shelter (with a-b) Patella caerulea and d-f) Patella ferruginea); c) modern Patellidae (Patella caerulea) [c) arrows: notches; fragmentation of the shell according to C. Dupont (2006) typology: a-b) complete shell, d) ring of shell, e) crescent-shaped fragment of shell equal to a half ring, f) crescent-shaped fragment of shell smaller than a half ring]; $g-j$ ) Mytilidae [h-j: Mytilus galloprovincialis, g-h) Mytilidae from Alain rock shelter, i-j) modern Mytilidae] [h-j) arrows: notches]; k-I) Trochidae (Phorcus turbinatus) from Alain rock shelter [l) arrow: lack of apex]; $\mathrm{m}$ ) shell fragments of Muricidae (Stramonita haemastoma) from Alain rock shelter; n) Tubiform from Alain rock shelter.

(Photos E. Campmas)

\section{3 - Non-food resources}

41 The use of certain shells as ornaments (Glycymerididae and tusk shells) had already been observed by P. Pallary (1934) and H. Sidi Maamar (1987).

42 Abundant scaphopod fragments were recorded (fig. 6). They are of different colours (fig. 6a) and some of them still bear pigment residues (fig. $6 \mathrm{~b}$ and d2). Large-sized scaphopod fragments are blunted, particularly in the aperture zones and can present striations linked to abrasion (fig. 6e). Two scaphopods are still nested together, maintained by concretionary sediment (fig. 6c).

43 Many of the Glycymerididae valves of Glycymeris nummaria are completely blunted (after fragmentation) (fig. 7a-g, j-l and n-p). Many of them bear perforations (fig. 7a-g; $\sim 25 \%$ of the hook zones). The latter can also be broken or open (fig. 7j-1; $\sim 30 \%$ of the hook zones). Some perforations may be of natural origin (fig. $7 \mathrm{~m}$ and q), caused by the erosion of the convex parts (hook, edge of shell, hinge teeth) on the sand by the backwash of the waves or by the action of carnivore molluscs, such as certain Naticidae or Muricidae, for example, which pierce mollusc shells with their radula in order to eat 
the soft parts (Loppens 1926; Dupont 2006, 2014; Cabral and Martin 2016). However, some perforations present marks (striations, indentations) (fig. $7 \mathrm{v}$ and $\mathrm{w}$ ) suggesting deliberate perforations (by scraping and/or light percussion). Rare residues of pigments were identified on the shells observed at high magnifications. Several specimens of Glycymerididae cf. Glycymeris pilosa $(\mathrm{N}=12)$, with a reduced shell thickness (fig. $7 \mathrm{~h}$ and $\mathrm{u}$ ), do not present the same patina and are less blunted. Like for the Glycymerididae cf. Glycymeris nummaria, some shells bear perforations in the hook zone, but not all the valves are whole.

The Cardiidae are less patinated than the Glycymerididae cf Glycymeris nummaria, but one of them (Acanthocardia tuberculata) also bears a perforation in the hook zone (fig. 7i).

Turritellidae shells present perforations (fig. 8). One of the perforated shells bears wear on the edges of the perforation as well as around the peristome. Residues of pigment were also observed on this shell.

46 As Scaphopods practically only live in deep waters (Lindner 2015), the shells must have been gathered in secondary position, once they had been washed up on the sand, or even in fossil state. The state of erosion of the Glycymerididae cf. Glycymeris nummaria shells suggests that they were collected a long time after the death of the molluscs, rolled on the beach or more probably in fossil state. Thus, the presence of blunted edges, natural perforations, or animals a long way from their natural environment (deep waters) indicates that Dentaliidae, Glycymerididae, Cardiidae (Acanthocardia tuberculata) and Turritellidae were not gathered to be eaten. P. Pallary (1934) already indicated that some of these fossils could come from the Miocene Sahelian limestones (including many bivalve shells, such as Pectenidae and Ostreidae) (Gentil 1903; Roger 1942; Freneix, Saint-Martin, Moissette 1987) or Upper Pliocene and Pleistocene raised beaches from the region of Oran. The acquisition of materials in fossil state is also likely for the megalodon tooth (fig. 4c) or the fossil bivalve imprints (fig. 4a, b). Indeed, P. Pallary (1934 - p. 43) already suggested that "we found several imprints on Sahelian limestone that were cut out following the exact contours of the valves. These objects were thus gathered intentionally". However, for the scaphopods, P. Pallary (1934 - p. 44) noted that 'they are absent from raised beaches, but we find them in Pliocene sites, where they are rare" and he suggested a more distant origin for them.

Some perforations, wear and pigment residues show the use of these elements, probably as ornaments.

As for the proportions, in our case, the mollusc shells used for non-dietary purposes, particularly Scaphopods, are better represented than those belonging to consumed molluscs. These frequencies are similar to the observations made by P. Pallary (1934) "the most abundant are the tusk shells... then the scallops" (Pallary 1934 - p. 42). However, as the excavations took place in the 1930s, it is probable that the archaeologists preferentially conserved the remains used for ornamental purposes.

\section{4 - Discussion}

\section{1 - Exploitation of marine molluscs during the Iberomaurusian}

According to H. Camps-Fabrer (1994), Patellidae are widespread in the Iberomaurusian sites of the Mediterranean coast. For example, in Rassel Cave (Algeria, fig. 1-17), C. 
Brahimi (1970) notes the presence of Trochidae and Patellidae. These families are also well represented in the Babor region (Afalou Bou Rhummel, Tamar Hat et Taza 1; fig. 1-18-19-20) (Arambourg et al. 1934; Saxon et al. 1974; Merzoug 2017). In Rachgoun (Algeria, fig. 1-12), H. Camps-Fabrer (1994) indicates that sea urchin spicules are present, as well as Mytilidae, Patellidae and Trochidae shells. However, she notes the absence of fish remains, which is not the case at Abri Alain or in the sites in the Babor region (Arambourg et al. 1934; Saxon et al. 1974; Merzoug 2017). Our results concerning the malacofauna consumed by the Iberomaurusian groups of Abri Alain thus confirm and complete our observations. Like on the Mediterranean coast, data from the Moroccan Atlantic (Smugglers' Cave - la grotte des Contrebandiers), Témara, Morocco, fig. 1-3) suggest that the Iberomaurusian groups mainly ate Mytilidae and Patellidae, but also to a lesser extent Trochidae and Muricidae (Steele and Alvarez-Fernandez 2011). The mention of a Haliotis remain in Smugglers' Cave is also noteworthy (Steele and Alvarez-Fernandez 2011). In addition, in his publication, P. Pallary (1934) indicates that the marine molluscs, and in particular those that were consumed, are mainly present in the "black layer". The same applies to the Babor region where the mollusc shells are mainly present in the upper levels of the stratigraphies (Arambourg et al. 1934; Saxon et al. 1974; Merzoug 2017) and where, for example, the increase in fishing resources, with Patellidae and Trochidae in particular (mainly Phorcus turbinatus), is observed towards 17-16 ka cal BP at Taza 1 (fig. 1-20, Merzoug 2017). These observations point towards a diversification of the exploited resources, in particular molluscs, and especially terrestrial molluscs, from the recent phase of the Iberomaurusian (Taylor et al. 2011; Lubell 2004; Lubell and Barton 2011). At Abri Alain, P. Pallary (1934 - p. 25) also indicates that marine molluscs are much less abundant than terrestrial molluscs, but an analysis of the latter, represented by many comestible (Helix aspersa, Pseudotachea splendida, Sphincterochila candidissima, Otala punctata) and intrusive taxa (Rumina decollata, Helicidae) (Sidi Maamar 1987), would lead to a better assessment of their contribution to the Iberomaurusian diet.

Perforated marine mollusc shells, collected in a non-dietary, probably symbolic aim, are mentioned in different, mainly Moroccan sites (Ifri n'Ammar, fig. 1-8, Moser 2003; Taforalt, fig. 1-9, Camps 1974; Merzoug 2005 according to Roche, 1963), Algerian (Mouillah, fig. 1-11, Camps 1974; Camps-Fabrer 1994; Rassel, fig. 1-17, Brahimi, 1970, Camps, 1974; Camps-Fabrer 1994; Afalou-Bou-Rhummel, fig. 1-18, Merzoug 2005 according to Hachi 2003; Tamar-Hat, fig. 1-19, Camps-Fabrer 1994, Merzoug 2005 according to Hachi 2003) and Tunisian (Oued el-Akarit, fig. 1-22, Camps-Fabrer 1994). Like at Abri Alain, they correspond mainly to Turritellidae, Dentaliidae and Glycymerididae. However, Columbeliidae, Pectenidae, Cardiidae, Spondylidae and Nassariidae are more rarely mentioned. As for Glycymerididae, G. Camps (1974 - p. 99) even suggested that the Iberomaurusians used "already worn and sometimes naturally perforated scallop shells [...] in rare cases they attempted to perforate the hook of the shells themselves by wearing it down by rubbing, rather than carving into it with a drill". These observations are similar to what we describe at Abri Alain. If at Abri Alain, the majority of the shells seem to have been used for ornamental purposes, the more recent excavations at Afalou Bou Rhummel (1983-1993) and Taza 1 (1984-1993) showed that limpet remains, for example are more abundant than the molluscs not used for dietary purposes (Hachi 2003; Merzoug 2017). Our work provides some information on the elements making up the ornaments used during the Iberomaurusian, but only an indepth analysis of the ornamental elements will contribute to the development of 
current research on this culture, and help to define its identity and the settlement dynamics in northwest Africa.

Figure 6 - Scaphopods from the Alain rock shelter.

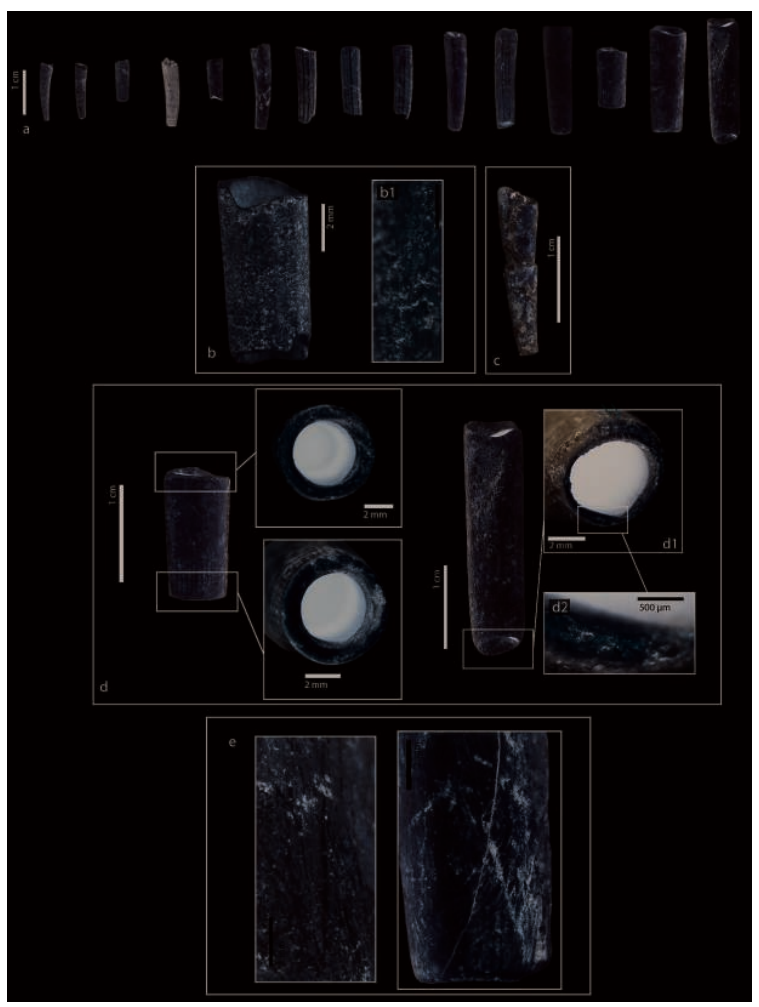

a) examples of surface aspects and colorations; b) with pigment residues; c) shells still nested; d) fragments with smooth openings [note that the worked right specimen is the only one difficult to identify, but the presence of two still slightly visible longitudinal ornamental ribs (arrows in d1) suggests its attribution to scaphopods]; d2: with pigment residues; e) abrasion marks.

(Photos E. Campmas) 
Figure 7 - Non consumed bivalves.

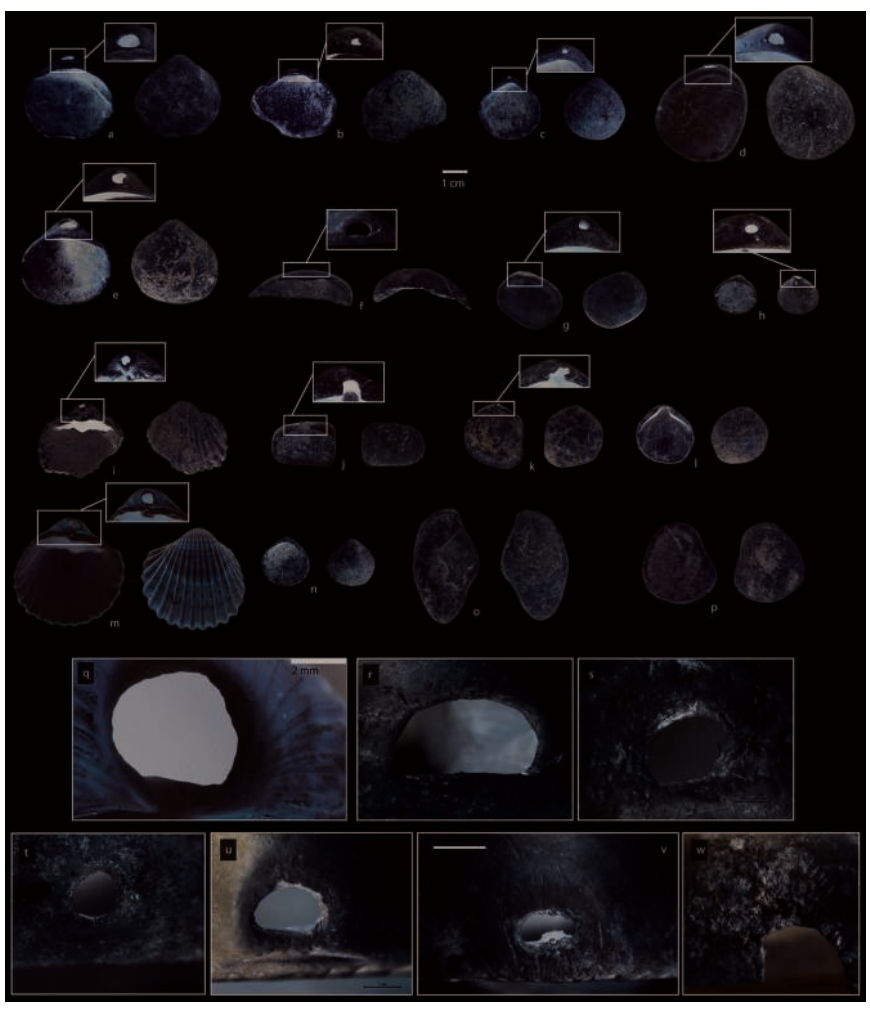

a-l, $n-p, r-w)$ bivalves from Alain rock shelter, $m, q$ ) modern bivalves collected on the Skhirat beach (Morocco) [a-g, j-l; n-p, r-w) Glycymerididae cf Glycymeris nummaria, h) Glycymerididae cf. Glycymeris pilosa; j, m) Cardiidae (Acanthocardia tuberculata), a-i, m) with perforation, $\mathrm{k}-\mathrm{I}$ ) "open" perforation, $\mathrm{n}$ ) without perforation, o-p) fragments without perforation, $q-w$ ) observation of perforations at high magnification: q) modern natural perforation, v) perforation associated with streak-marks, w) "open" perforation associated with punctures.

(Photos E. Campmas) 
Figure 8 - a) Turritella triplicata with a perforation; b) perforation; arrows) pigment residues).

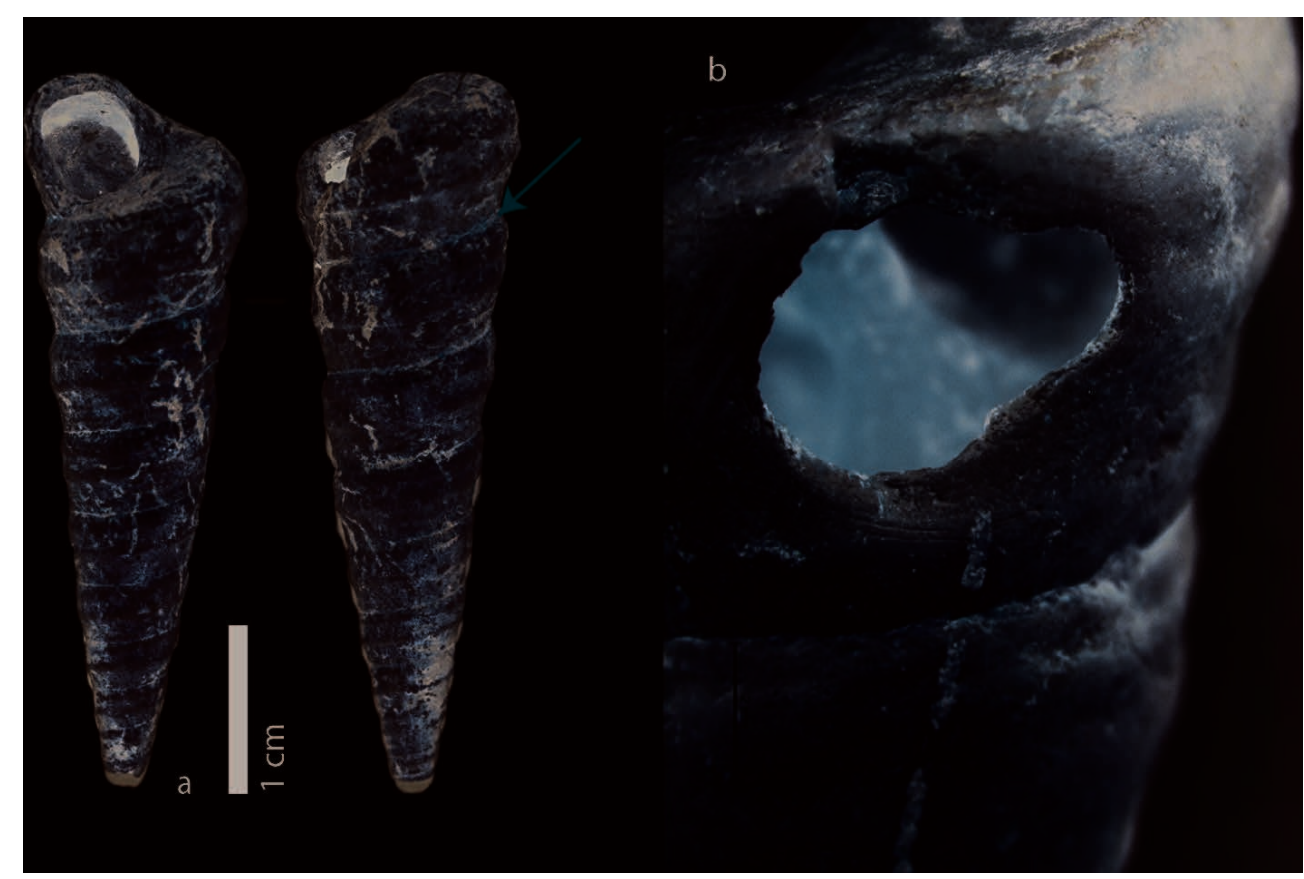

(Photos E. Campmas)

\section{2 - Diachronic and geographic comparisons in the Mediterranean basin}

The marine molluscs consumed during the Iberomaurusian, in Abri Alain and the Babor regions, namely Patellidae, Mytilidae and Trochidae, are similar to those described for the Middle Stone Age in North Africa (130-60 ka) on the Moroccan Atlantic coast of Témara-Rabat (Steele and Alvarez-Fernandez 2011, 2012; Campmas et al. 2016, accepted). However, differences emerge, particularly for Ostridae, Pectenidae or Cerastoderma edule, the status of which has still to be defined at Abri Alain. For periods contemporaneous or sub-contemporaneous with the Iberomaurusian, this malacological spectrum is similar to that described in other geographic zones, like in the pre-LGM (Late Glacial maximum), LGM and post-LGM levels of Europe and the Levant, for example at Riparo Mochi (Italy) (Stiner 1999) and Ksâr'Akil (Lebanon) (Curry 2015; Bosch et al. 2015). In Libya, in the Oranian and Capsian levels of Haua Fteah, Trochidae (Phorcus turbinatus) and Patellidae (Patella caerulea) are preponderant (Hunt et al. 2011; Prendergast et al. 2016). On the other hand, in the Capsian site SHM-1 of the sebkhalagoon of Menjel (Tunisia), Cardiidae (Cerastoderma glaucum) dominate the consumed marine malacofauna, even though Patellidae, Trochidae, Muricidae, Ostreidae and Veneridae also contributed to the diet (Mannino and Mazzanti 2013). In the Neolithic sites of Tarfaya (Morocco), P. Brebion (1981) suggests that humans consumed mainly Patellidae and Muricidae, but also other taxa such as Trochidae, bivalves or Volutidae. He notes the absence of transformation of the malacofauna into ornaments, but he suggests that certain Cymbium cf. tritonis were used as recipients. During the LGM and post-LGM in Europe, molluscs from sandy and /or lagoon environments (Ostridae, Cardiidae) are also described in variable proportions, along with marine molluscs from rocky environments (Patellidae, Trochidae, Mytilidae) (Aura Tortosa 2002; Fa 2008; 
Jorda Pardo 2009; Jordá Pardo et al. 2016; Colonese et al. 2011; Stiner and Munro 2011). A.C. Colonese et al. (2011) suggest that in Europe, the intensification of the exploitation of marine malacofauna occurred alongside an intensification of fishing activities, the consumption of birds and marine mammals, as well as an increase in the transport distances of marine resources. The same applies to South Africa where the exploitation of marine molluscs is recorded during the Middle Stone Age, but seems to become more intensive during the Later Stone Age, with significant densities of marine molluscs in the archaeological levels after $10 \mathrm{ka}$ (Jerardino 2016). The Abri Alain infilling contains more mollusc shells in the upper part, along with remains of fish, aquatic birds (Anatidae), (Chibane 2016), like in the Babor sites and particularly Taza 1 (Merzoug 2017), and could thus be assimilated to this intensification model of the exploitation of marine resources, which would be linked, in North Africa, to the deposition of "black powdery deposits", dated to about 16-12 ka cal BP. Still in North Africa, but in the Capsian, this diversification of the exploited resources is also characterized by the consumption of a large number of terrestrial molluscs (Lubell 2004; Colonese et al. 2011), which seemed to begin in the recent phase of the Iberomaurusian (Taylor et al. 2011). However, it is important to note that the powdery accumulations rich in terrestrial and/or marine molluscs attributed to the northeast African Capsian (Lubell 2004) also seem to be a characteristic of the end of the Iberomaurusian in the west of Algeria or the east of Morocco (e.g. Pallary 1934; Camps 1974; Moser 2003; Barton et al. 2013). This is also the case for the Neolithic occupations in the coastal zones of the Moroccan Atlantic coastline, rich in mussel shells (Nespoulet et al. 2008).

No Nassarius shells have been observed in Abri Alain, whereas this shell was widely used during the Aterian (Middle Stone Age of North Africa) for ornamental purposes (Vanhaeren et al. 2006; Bouzouggar et al. 2007; d'Errico et al. 2009; Nami and Moser 2010; Dibble et al. 2012; Eiwanger et al. 2012; El Hajraoui, Oudouche, Nespoulet 2012; Bar-Yosef Mayer 2015). However, several mentions of Nassariidae are made during the Iberomaurusian, particularly at oued el-Akarit (Tunisia) (Camps 1974). Nevertheless, in this locality, alongside the description of sites "with bladelets", a Middle Stone Age site is also mentioned (Zoughlami et al. 1985), which raises questions on the use of Nassarius by Middle Stone Age and Iberomaurusian groups, the pollution of the Iberomaurusian site by Aterian inputs or the gathering of Aterian Nassarius by Iberomaurusians. A shell from the Nassariidae family is also mentioned in Rassel Cave (fig. 1-17), but it appears to be a Nassarius granum according to Brahimi (1970). Nassariidae are described at Tamar Hat, with a low frequency but in all the levels, however this family is only represented by the Tritia genus (Tritia reticulata, Tritia incrassata and Tritia cf. mutabilis) (Saxon et al. 1974). During the Aterian, Nassarius gibbosulus and/or Nassarius circumcintus appear to be preponderant. However, Nassariidae (Nassarius nitidus, Nassarius gibbosulus, Nassarius mutabilis) are described as ornaments in the Capsian site of SHM-1 (Mannino and Mazzanti 2013) and a specimen completely polished to the columelle was identified in the Capsian site of El Mekta (Gobert 1951; Rahmani 2003). Nassariidae thus seem to have been used as ornaments in North Africa at different periods. The main difference between Aterian and Iberomaurusian ornaments in marine malacofauna seems to be the diversity, rather than the type of taxa used. This diversity is much more developed during the Iberomaurusian, the Capsian or the Early Neolithic in North Africa (CampsFabrer 1994; Mannino and Mazzanti 2013; Kherbouche et al. 2014). It is important to note that in an Early Neolithic level (with Cardial pottery) at Ifri Ouzabour (Rif Oriental, Morocco), a Glycymerididae shell was also used as an ornament. This perforated shell is 
accompanied by two other non-perforated Glycymerididae (Nekkal et al. 2015). According to Nekkal et al. (2015), the perforation near the hook was produced by percussion, which recalls the observations made at Abri Alain. This diversity is also observed in the Upper Palaeolithic and the Epipalaeolithic of the Levant and Europe [e.g. Ucagizli Cave (Turkey) (Stiner et al. 2002; Stiner 2003), Riparo Mochi (Italy) (Stiner 1999), Ksâr'Akil (Lebanon) (Bosch et al. 2015)] or again for the Mesolithic and the Neolithic in Europe (Rigaud 2011). We note strong similarities in the taphonomic aspect of the malacofauna from the Neolithic occupation in Spain (Caserna de Sant Pau del Camp) with the aspect of the Glycymerididae from Abri Alain, whether they are whole or fragmented and eroded after fragmentation. L. Lloveras et al. (2014) indicate that the presence of these shells at Caserna de Sant Pau del Camp does not seem to be in keeping with the geomorphological data and the spatial distribution. They suggest that they are not related to a storm front deposit. At Abri Alain, the deposits, in particular the black powdery layer, do not seem to be related to a storm front either. L. Lloveras et al. (2014) estimate that their higher concentration around the graves could attest to their use as ornaments. Nonetheless, these shells are not directly linked to the grave deposit, and no spatial concentration was linked to workshop zones. We also suggest that they were used for ornamentation at Abri Alain. On the other hand, although F. Doumergue (1935) mentions the presence of two human remains (phalanges), no grave has been identified. Their use as an offering linked to grave structures can thus be ruled out at Abri Alain. L. Lloveras et al. (2014) suggest that in Spain these shells could have been used for the production of bracelets, whereas the presence of perforations at Abri Alain could point to their use as hanging objects. This difference in function could be linked to the chronological, geographic and functional variations of the sites or even to the excavation methods, with the potential absence of certain elements at Abri Alain. In addition, it is important to note that at Aviones (Spain), J. Zilhão et al. (2010) suggest that Neanderthals used different blanks for adornments, including Acanthocardia tuberculata and Glycymeris nummaria, like at Abri Alain. Lastly, another interesting element concerns the scaphopods, which play an important role at Abri Alain and which are also present during the Natufian (Levant, 14.5-11.5 ka cal BP), during which marine molluscs and fish were also consumed (Bar-Yosef Mayer 2008; Bar-Yosef Mayer and Zohar 2010). Therefore, these observations raise questions concerning the behavioural convergences/recurrences of different human lineages at distinct periods in similar environments, the reliability of the stratigraphic sequences, or diffusion phenomena (of materials, ideas and/or populations) around the Mediterranean basin between 16 and $12 \mathrm{ka}$ cal BP.

\section{Conclusion}

The malacological collection from Abri Alain comes from an excavation carried out at the beginning of the $20^{\text {th }}$ century. This collection has undergone a complex history, perhaps with different occupation periods, but has nonetheless yielded unprecedented results on subsistence and the symbolic behaviour of Iberomaurusian groups. The latter collected molluscs from rocky biotopes (mainly Patellidae, Mytilidae, Trochidae) in the intertidal zone, probably at low tide. The Muricidae, Ostreidae, Pectenidae, Cerastoderma edule could also have been consumed, but their status has yet to be defined. The Iberomaurusians also used a wide diversity of marine mollusc shells, gathered in secondary position, to make ornamental elements (Dentaliidae, 
Glycymerididae, Cardiidae, Turritellidae). For the Iberomaurusians, this collection from the region of Oran reveals significant similarities with the Babor region (Merzoug 2017). The exploitation of molluscs for dietary and symbolic purposes, is also recorded during the Middle Stone Age / Middle Palaeolithic, but seems to become more intensive during the Later Stone Age / Upper Palaeolithic / Epipalaeolithic, in Africa and in Europe. The powdery black deposit with abundant mollusc shells at Abri Alain, dated to about 15-12 ka cal. BP, thus seems to match this model. Nonetheless, although this revision of the material provides information on the characterization of the marine malacofauna consumed by the Iberomaurusians, research on series from exhaustive excavations assessing species diversity, specimen selections, collecting, processing and preparation methods, as well as the post-depositional degradation of the shells must be carried out. As for the malacofauna used for ornaments, we identified elements with traces of shaping and use associated with the presence of pigment residues. Nonetheless, for a better understanding of the markers of identity and symbolic systems of Iberomaurusian groups, the analysis of these shells requires further investigation (blank selection, transformation methods and use wear).

\section{BIBLIOGRAPHY}

\section{Bibliographic references}

ABBAR H. 2014 - La faune ibéromaurusienne de la couche jaune de l'Abri Alain (Oran, Algérie): Etude Paléontologique et Paléoécologique. Paris : Muséum National d'Histoire Naturelle. Mémoire de Master 1.

ALDEIAS V., GUR-ARIEH S., MARIA R., MONTEIRO P. et CURA P. 2016 - Shell we cook it? An experimental approach to the microarchaeological record of shellfish roasting. Archaeological Anthropological Science, 1-19.

AOUDIA-CHOUARKI L. 2013 - Pratiques funéraires complexes: réévaluation archéo-anthropologique des contextes ibéromaurusiens et capsiens (Paléolithique supérieur et Epipaléolithique, Afrique du Nord-Ouest). Bordeaux : Université Bordeaux 1. Thèse de doctorat.

ARAMBOURG C. 1927 - Les Poissons Fossiles d'Oran. Matériaux pour la Carte Géologique de l'Algérie, 6, $298 \mathrm{p}$.

ARAMBOURG C., BOULE M., VALLOIS H., VERNEAU R. 1934 - Les grottes paléolithiques des Beni Ségoual (Algérie). Archives de l'Institut de Paléontologie Humaine, 13, 242 p.

AURA TORTOSA J.E. 2002 - The far south: the Pleistocene-Holocene transition in Nerja Cave (Andalucía, Spain). Quaternary International, 93-94, p. 19-30.

BALOUT L. 1950 - Préhistoire de l'Afrique du Nord essai de chronologie. Paris : Arts et métiers graphiques. 
BARTON R.N.E., BOUZOUGGAR A., COLLCUTT S.N., CARRIÓN MARCO Y., CLARK-BALZAN L., DEBENHAM N.C., MORALES J. 2016 - Reconsidering the MSA to LSA transition at Taforalt Cave (Morocco) in the light of new multi-proxy dating evidence. Quaternary International, 413, p. 36-49.

BARTON N., BOUZOUGGAR A., COLLCUTT S.N., HIGHAM T.F.G., HUMPHREY L.T., PARFITT S., RHODES E., SCHWENNINGER J.-L., STRINGER C., TURNER E., WARD S. 2007 - Abrupt Climatic Change and Chronology of the Upper Palaeolithic in Northern and Eastern Morocco. In : P. Mellars, K. Boyle., O. Bar-Yosef, C. Stringer (Ed.), Rethinking the Human Revolution New Behavioural and Biological Perspectives on the Origin and Dispersal of Modern Humans. Oxford: Oxbow Books, p. 177-190.

BARTON R.N.E., BOUZOUGGAR A., HOGUE J.T., LEE S., COLLCUTT S.N. et DITCHFIELD P. 2013 Origins of the Iberomaurusian in NW Africa: New AMS radiocarbon dating of the Middle and Later Stone Age deposits at Taforalt Cave, Morocco. Journal of Human Evolution, 65, p. 266-281.

BARTON N., BOUZOUGGAR A., HUMPHREY L., BERRIDGE P., COLLCUTT S., GALE R., PARFITT S., PARKER A., RHODES E. et SCHWENNINGER J.-L. 2008 - Human Burial Evidence from Hattab II Cave and the Question of Continuity in Late Pleistocene-Holocene Mortuary Practices in Northwest Africa. Cambridge Archaeological Journal, 18, p. 195-214.

BAR-YOSEF MAYER D.E. 2008 - Dentalium Shells Used by Hunter-Gatherers and Pastoralists in the Levant. Archaeofauna, 17, p. 103-110.

BAR-YOSEF MAYER D.E. 2015 - Nassarius shells: Preferred beads of the Palaeolithic. Quaternary International, 390, p. 79-84.

BAR-YOSEF MAYER D.E., ZOHAR I. 2010 - The role of aquatic resources in the Natufian Culture. Eurasian Prehistory, 7, p. 29-43.

BOSCH M.D., MANNINO M.A., PRENDERGAST A.L., O'CONNELL T.C., DEMARCHI B., TAYLOR S.M., NIVEN L., PLICHT J. VAN DER et HUBLIN J.-J. 2015 - New chronology for Ksâr 'Akil (Lebanon) supports Levantine route of modern human dispersal into Europe. Proceeding of National Acadademic Sciences of United States of America, 112, p. 7683-7688.

BOUZOUGGAR A., BARTON R.N.E., BLOCKLEY S., BRONK-RAMSEY C., COLLCUTT S.N., GALE R., HIGHAM T.F.G., HUMPHREY L.T., PARFITT S., TURNER, E. et WARD S. 2008 - Reevaluating the Age of the Iberomaurusian in Morocco. African Archaeological Review, 25, p. 3-19.

BOUZOUGGAR A., BARTON N., VANHAEREN M., D'ERRICO F., COLLCUTT S., HIGHAM T., HODGE E., PARFITT S., RHODES E., SCHWENNINGER J.-L., STRINGER C., TURNER E., WARD S., MOUTMIR A. et STAMBOULI A. 2007 - 82,000-year-old shell beads from North Africa and implications for the origins of modern human behavior. Proceeding of National Academic Sciences of United States of America, 104, p. 9964-9969.

BRAHIMI C. 1970 - L'Ibéromaurusien du littoral de la région d'Alger, Alger : Mémoire du CRAPE, 23, $154 \mathrm{p}$.

BREBION P. 1981 - Les gastéropodes du Néolithique de Tarfaya (Maroc). In : Préhistoire AfricaineMélanges offerts au Doyen Lionel Balout, p. 253-256.

BUCQUOY D.E., DAUTZENBERG P., DOLLFUS G. 1882-1886 - Mollusques marins du Roussillon, Tome Ier, Gastéropodes, Paris : J.B. Baillières \& Fils.

BUCQUOY D.E., DAUTZENBERG P., DOLLFUS G. 1887-1898 - Mollusques marins du Roussillon, Tome II, Pélécypodes, Paris : J.B. Baillières \& Fils.

CABRAL J.P. et MARTINS J.M.S. 2016 - Archaeological Glycymeris glycymeris shells perforated at the umbo: Natural or man-made holes? Journal of Archaeological Science: Reports, p. 474-482. 
CAMPMAS E., AMANI F., MORALA A., DEBÉNATH A., EL HAJRAOUI M.A. et NESPOULET R. 2016 Initial insights into Aterian hunter-gatherer settlements on coastal landscapes: The example of Unit 8 of El Mnasra Cave (Témara, Morocco). Quaternary International, 413, p. 5-20.

CAMPMAS E., CHAKROUN A., CHAHID D., LEBON M., EL HAJRAOUI M.A., NESPOULET R. accepté Subsistance en zone côtière durant le Middle Stone Age en Afrique du Nord : Exemple des données préliminaires sur l'Unité 8 de la grotte d'El Mnasra (Témara, Maroc), In: Actes Du 141e Congrès Du CTHS, Rouen 2016.

CAMPS G. 1974 - Les Civilisations préhistoriques de l'Afrique du Nord et du Sahara. Paris : Doin.

CAMPS-FABRER H. 1994 - Coquillages. In : G. Camps (Ed.), Encyclopédie berbère. Louvain : Peeters, p. 2088-2092.

CHAKROUN A. 2006 - Étude sédimentologique et paléontologique des affleurements du Quaternaire le long de la côte Nord Orientale de la Tunisie. Tunis : Université de Tunis - Perpignan : Université de Perpignan. Thèse de doctorat.

CHAKROUN A., ZAGHBIB-TURKI D. sous presse - Facies and fauna proxies used to reconstruct the MIS 5 and MIS 7 coastal environments in eastern Tunisia. Geological Quarterly.

CHAKROUN A., ZAGHBIB-TURKI D., MISKOVSKY J. C., DAVAUD E. 2009 - Two transgressive cycles in coastal deposits of the Cap Bon peninsula, Tunisia. Quaternaire, 20, p. 215-226.

CHAKROUN A., ZAGHBIB-TURKI D., MONCEF TURKI M. 2016 - The Upper Pleistocene deposits in Rafraf (Northeastern Tunisia): new data on the Persististrombus latus level. Arabian Journal of Geosciences, 9, p. 1-13.

CHIBANE S. 2016 - Étude taphonomique et archéozoologique de la faune ibéromaurusienne de l'abri Alain (Oran, Algérie). Toulouse : Université Toulouse Jean Jaurès. Mémoire de Master 2.

COLONESE A.C., MANNINO M.A., BAR-YOSEF MAYER D.E., FA D.A., FINLAYSON J.C., LUBELL D., STINER M.C. 2011 - Marine mollusc exploitation in Mediterranean prehistory: An overview. Quaternary International, 239, p. 86-103.

CURRY A. 2015 - Ancient humans brought tools to Europe. Nature-News.

DE GROOTE I. et HUMPHREY L.T. 2015 - Characterizing evulsion in the Later Stone Age Maghreb: Age, sex and effects on mastication. Quaternary International, 413, p. 50-61.

D'ERRICO F., VANHAEREN M., BARTON N., BOUZOUGGAR A., MIENIS H., RICHTER D., HUBLIN J.-J., MCPHERRON S., LOZOUET P. 2009 - Additional evidence on the use of personal ornaments in the Middle Paleolithic of North Africa. Proceeding of National Academic Sciences of United States of America, 106, p. 16051-16056.

DIBBLE H., ALDEIAS V., ALVAREZ-FERNANDEZ E., BLACKWELL B., HALLETT-DESGUEZ E., JACOBS Z., GOLDBERG P., LIN S., MORALA A., MEYER M., OLSZEWSKI D., REED K., REZEK Z., RICHTER D., ROBERTS R., SANDGATHE D., SCHURMANS U., SKINNER A., STEELE T., EL-HAJRAOUI M. 2012 New excavations at the site of Contrebandiers Cave, Morocco. PaleoAnthropology, 145-201. DOUMERGUE F. 1935 - Grotte démantelée des carrières d'Eckmühl. Bulletin de la Société de géographie et d'archéologie de la province d'Oran.

DUPONT C. 2006 - La malacofaune de sites mésolithiques et néolithiques de la façade atlantique de la France: Contribution à l'économie et à l'identité culturelle des groupes concernés. BAR International Series 1571.

DUPONT C. 2014 - Do not mix up apples and oranges! A concept applied to shells from the Mesolithic. In : J. J. Cantillo, D. Bernal, J. Ramos (Ed.), Moluscos y purpura en contextos arqueologicos 
atlantico-mediterraneos: Nuevos datos y reflexiones en clave de proceso historico. Actas de la III reunion Cientifica de la peninsula Iberica, Cádiz (décembre 2012), Cádiz, Servicio de Publicaciones de la Universidad de Cádiz, p. 41-50.

EIWANGER J., MIKDAD A., MOSER J. et NAMI M. 2012 - Découverte de coquilles perforées de type Nassarius au site Ifri n'Ammar (Rif Oriental, Maroc). Bulletin d'Archéologie Marocaine, XXII, p. 9-15.

EL HAJRAOUI M.A., OUDOUCHE H. et NESPOULET R. 2012. Etude des coquilles perforées découvertes à Témara. In : M.A El Hajraoui, R. Nespoulet, A. Debénath, H. L. Dibble (Ed.), La Préhistoire de La Région de Rabat-Témara. Rabat: Villes et sites Archéologiques du Maroc, Vol. III, Rabat: Publication du Ministère de la Culture et de l'Institut National des Sciences de l'Archéologie et du Patrimoine, p. 191-199.

ESU D. et GIROTTI O. 2010 - The late Oligocene molluscan fauna from Otranto (Apulia, southern Italy): an example of alternating freshwater, lagoonal and emerged environments, 53, p. 137-174.

FA D.A. 2008 - Effects of tidal amplitude on intertidal resource availability and dispersal pressure in prehistoric human coastal populations: the Mediterranean-Atlantic transition. Quaternary Science Review, 27, p. 2194-2209.

FEKI M. 1975 - Paléoécologie du Pliocène marin au Nord de la Tunisie. Annales des Mines et de la Géologie, 27, 194p.

FRENEIX S., SAINT MARTIN J.-P. et MOISSETTE P. 1987 - Bivalves Ptériomorphes du Messinien d'Oranie (Algérie occidentale), Bulletin du Muséum National d'Histoire Naturelle, Paris, 9, p. 3-61.

GENTIL L. 1903 - Étude géologique du bassin de la Tafna. Bulletin du Service des Cartes Géologiques de l'Algérie, 4, $425 \mathrm{p}$.

GOBERT E.G. 1951 - El Mekta, station princeps du Capsien. Karthago, III, p. 1-79.

GRANCHON P. 1987 - L'industrie ibéromaurusienne de l'abri Alain, Oran-Algérie. Paris : Université de Paris I. Mémoire de maîtrise.

HACHI S. 2003 - Les cultures de l'Homme de Mechta-Afalou. Le gisement d'Afalou-Bou-Rhummel (massif des Babors, Algérie), les niveaux supérieurs 13 000-11 000 BP. Mémoire du Centre National de Recherches Préhistoriques Anthropologiques et Historiques, 2, 256 p.

HADJOUIS D. 2002 - Les hommes du Paléolithique supérieur d'Afalou Bou Rhummel (Bedjaia, Algérie). Interprétation nouvelle des cinétiques cranio-faciales et des effets de l'avulsion dentaire. Malformations crâniennes, troubles de la croissance, anomalies et maladies alvéolodentaires. L'Anthropologie, 106, p. 337-375.

HELLAL H. 2005. L'Ibéromaurusien de l'abri Alain (Algérie occidentale). Approche Technotypologique des industries lithiques. Paris : Université de Paris I. Mémoire de DEA.

HOGUE J.T., BARTON R.N.E. 2016 - New radiocarbon dates for the earliest Later Stone Age microlithic technology in Northwest Africa. Quaternary International, 413, p. 62-75.

HÖRNES M. 1852 -1856 - Die fossilen Mollusken des Tertiär-Beckens von Wien. I. Band. Univalven. Abh. K.K. Geol. Reichsanst, 1-10, 736 p.

HUMPHREY L.T., BELLO S.M., TURNER E., BOUZOUGGAR A. et BARTON N. 2012 - Iberomaurusian funerary behaviour: Evidence from Grotte des Pigeons, Taforalt, Morocco. Journal of Human Evolution, 62, p. 261-273.

HUMPHREY L.T., BOCAEGE E. 2008 - Tooth Evulsion in Maghreb: Chronological and Geographical Patterns. African Archaeological Review, 25, p. 109-123. 
HUMPHREY L.T., GROOTE I.D., MORALES J., BARTON N., COLLCUTT S., RAMSEY C.B., BOUZOUGGAR A. 2014 - Earliest evidence for caries and exploitation of starchy plant foods in Pleistocene hunter-gatherers from Morocco. Proceeding of National Academic Sciences of United States of America, 111, p. 954-959.

HUNT C.O., REYNOLDS T.G., EL-RISHI H.A., BUZAIAN A., HILL E., BARKER G.W. 2011 - Resource pressure and environmental change on the North African littoral: Epipalaeolithic to Roman gastropods from Cyrenaica, Libya. Quaternary International, 244, p. 15-26.

HUVET A. 2000 - Ressources génétiques et phylogéographie des huîtres creuses Crassostrea gigas et Crassostrea angulata: variabilité, différenciation et adaptation des populations naturelles et introduites. Tours : Université François Rabelais. Thèse de doctorat.

JERARDINO A. 2016 - On the origins and significance of Pleistocene coastal resource use in southern Africa with particular reference to shellfish gathering. Journal of Anthropological Archaeology, 41, p. 213-230.

JORDA PARDO J. 2009 - La malacofauna de la Cueva de Nerja (III): Evolución medioambiental y técnicas de marisqueo. Zephyrvs, 37.

JORDA PARDO J.F., AURA TORTOSA J.E., AVEZUELA ARISTU B., ÁLVAREZ-FERNANDEZ E., GARCIAPEREZ A. et MAESTRO A. 2016 - Breaking the waves: Human use of marine bivalves in a microtidal range coast during the Upper Pleistocene and the Early Holocene, Vestíbulo chamber, Nerja Cave (Málaga, southern Spain). Quaternary International, 407, p. 59-79.

KHERBOUCHE F., HACHI S., ABDESSADOK S., SEHIL N., MERZOUG S., SARI L., BENCHERNINE R., CHELLI R., FONTUGNE M., BARBAZA M., ROUBET C. 2014 - Preliminary results from excavations at Gueldaman Cave GLD1 (Akbou, Algeria). Quaternary International, 320, 109-124.

LINDNER G. 2015 - Coquillages marins: Plus de 1000 espèces des mers du monde, Paris : Delachaux et Niestlé.

LINSTÄDTER J. 2008 - The Epipalaeolithic-Neolithic-Transition in the Mediterranean region of Northwest Africa. Quartär, 55, p. 33-54.

LINSTÄDTER J., EIWANGER J., MIKDAD A., WENIGER G.-C. 2012 - Human occupation of Northwest Africa: A review of Middle Palaeolithic to Epipalaeolithic sites in Morocco. Quaternary International, 274, 158-174.

LLOVERAS L., VICENTE O., MOLIST M., NADAL J., RIERA S., JULIÀ R., ESTRADA A. 2014 Interpretación tafonómica de la malacofauna marina en el yacimiento neolítico de la Caserna de Sant Pau del Camp (Barcelona). Archaeofauna, 23, 169-179

LOCARD A. 1892 - Les coquilles marines des côtes de France: Description des familles, genres et espèces, Paris : Librairie J.B. Baillières et Fils.

LOPPENS K. 1926 - La perforation des coquilles de Mollusques par des gastéropodes et des éponges. Annale Société Royale Zoologique de Belgique., LVII, p. 14-18.

LUBELL D. 2004 - Prehistoric edible land snails in the circum-Mediterranean: the archaeological evidence. In : J. Ph. Brugal, J. Desse (Ed.), Petits Animaux et Sociétés Humaines. Du Complément Alimentaire Aux Ressources Utilitaires. XXIVe Rencontres Internationales D'archéologie et D'histoire d'Antibes. Antibes (octobre 2003), Antibes, APDCA, p. 77-98.

LUBELL D. et BARTON N. 2011. Gastropods and humans in the late Palaeolithic and Mesolithic of the western Mediterranean basin. Quaternary International, 244, p. 1-4. 
MANNINO M.A. et MAZZANTI C. 2013 - Studi ed osservazioni preliminari sulla malacofauna dal sito capsiano costiero SHM-1 (Tunisia centrale). In : S. Mulazzani (Ed.), Le Capsien de Hergla (Tunisie): Culture, Environnement et Économie. Altkönigblick : Africa

Magna Verlag, p. 339-361.

MARIOTTI V., BELCASTRO M.G., CONDEMI S. 2016 - From corpse to bones: funerary rituals of the Taforalt Iberomaurusian population. BMSAP, 28, 60-65.

MARIOTTI V., BONFIGLIOLI B., FACCHINI F., CONDEMI S. et BELCASTRO M.G. 2009 - Funerary practices of the Iberomaurusian population of Taforalt (Tafoughalt; Morocco, 11-12,000BP): new hypotheses based on a grave by grave skeletal inventory and evidence of deliberate human modification of the remains. Journal of Human Evolution, 56, p. 340-354.

MARIOTTI V., CONDEMI S., BELCASTRO M.G. 2014 - Iberomaurusian funerary customs: new evidence from unpublished records of the 1950s excavations of the Taforalt necropolis (Morocco). Journal of Archaeological Science, 49, p. 488-499.

MERZOUG S. 2005 - Comportement de subsistance des Ibéromaurusiens d'après l'analyse archéozoologique des mammiferes de Tamar Hat, Taza 1 et Columata (Algérie). Paris : Muséum National d'histoire Naturelle. Thèse de doctorat.

MERZOUG S. 2008 - Étude archéozoologique des mammifères ibéromaurusiens de la collection Cadenat de Columnata (Tiaret, Algérie). In : H. Aouraghe, H. Haddoumi, K. El Hammouti, A. Oujda (Ed.), Le Quaternaire Marocain Dans Son Contexte Méditerranéen. Actes des quatrièmes rencontres des Quaternaristes marocaines (RQM4), Oujda (novembre 2007), Oujda, Publication de la Faculté des Sciences, Université Mohammed $1^{\text {er }}$, p. 255-264.

MERZOUG S. 2017 - Les comportements de subsistance en Afrique du Nord-Ouest durant la transition Pléistocène supérieur / Holocène : entre homogénéité et variations stratégiques. L'Anthropologie, 121, p. 189-203.

MERZOUG S., SARI L. 2008 - Re-examination of the Zone I Material from Tamar Hat (Algeria): Zooarchaeological and Technofunctional Analyses. African Archaeological Review, 25, p. 57-73.

MEZIANE K., KERFOUF A. 2013 - Biodiversité et distribution spatiale des mollusques de l'estran de la côte Ouest algérienne (cas des substrats durs). In : Actes Du 3ème Colloque International Sur La Biodiversité et Ecosystèmes Littoraux. 26-28 Novembre 2013, Oran, p. 97-104.

MOSER J. 2003 - La Grotte d'Ifri n'Ammar : Tome 1 L'Ibéromaurusien, Köln : Liden Soft.

NAMI M. et MOSER J. 2010 - La grotte d'Ifri n'Ammar: Le Paléolithique moyen, Verlag :

Forschungenzur Archäologie Außereuropäischer Kulturen.

NEKKAL F., LINSTÄDTER J., AOURAGHE H. et BOUGARIANE B. 2015 - Ifri Ouzabour : l'extrême extension de la culture cardiale sur le littoral méditerranéen sud (Rif Oriental, Maroc). Bulletin de l'Institut Scientifique, Rabat, Section Science de la Terre, 37, p. 55-76.

NESPOULET R., DEBENATH A., EL HAJRAOUI M.A., MICHEL P., CAMPMAS E., OUJAA A., BEN-NCER A., LACOMBE J.-P., STOETZEL E. et BOUDAD L. 2008 - Le contexte archéologique des restes humains atériens de la région de Rabat-Témara (Maroc): Apport des fouilles des grottes d'El Mnasra et d'El Harhoura 2. In : H. Aouraghe, H. Haddoumi, K. El Hammouti, A. Oujda (Ed.), Le Quaternaire Marocain Dans Son Contexte Méditerranéen. Actes des quatrièmes rencontres des Quaternaristes marocaines (RQM4), Oujda (novembre 2007), Oujda, Publication de la Faculté des Sciences, Université Mohammed 1 ${ }^{\text {er }}$, p. 356-375. 
NOUET J., CHEVALLARD C., FARRE B., NEHRKE G., CAMPMAS E., STOETZEL E., EL HAJRAOUI M.A. et NESPOULET R. 2015 - Limpet shells of the Aterian level 8 of El Harhoura 2 Cave (Témara, Morocco): Preservation state of crossed-foliated layers. PlosOne, 10, e0137162.

PALLARY P. 1934 - L'abri Alain, près d'Oran, Paris : Masson et Cie.

PASCAL M., CLERGEAU P., LORVELEC O. 2010 - Invasions biologiques et biologie de la conservation :essai de synthèse. Courrier de l'environnement de l'INRA, 40, p. 23-31.

PERRIER R. 1954 - La faune de France, IX : Vertébrés, Bryozoaires, Brachiopodes, Mollusques, Protocordés (Amphioxus - Tuniciers). Paris : Delagrave

POITRAT-TARGOWLA M.J. 1977 - Pathologie dento-maxillaire comparée des Hommes d'Afalou et de Taforalt (Ibéromaurusiens du Maghreb). Bulletin des Mémoires de la Société d'Anthropologie de Paris, 4, p. 389-394.

POTIEZ V.L.V. et MICHAUD A.L.G. 1838 - Galerie des mollusques ou catalogue méthodique et coquilles du Muséum de Douai. Paris : J.B. Baillières \& Fils.

PRENDERGAST A.L., STEVENS R.E., O'CONNELL T.C., FADLALAK A., TOUATI M., AL-MZEINE A., SCHÖNE B.R., HUNT C.O., BARKER G. 2016 - Changing patterns of eastern Mediterranean shellfish exploitation in the Late Glacial and Early Holocene: Oxygen isotope evidence from gastropod in Epipaleolithic to Neolithic human occupation layers at the Haua Fteah cave, Libya. Quaternary International, 407, p. 80-93.

RAHMANI N. 2003 - Le Capsien typique et le Capsien supérieur: évolution ou contemporanéité. Bordeaux : Université Bordeaux 1. Thèse de doctorat..

RAMPAL J. 1965 - Utilisation des dents radulaires pour la systématique des Patelles Méditerranéennes. Revue des Travaux de l'Institut de pêche maritime, 29, p. 205-210.

RIGAUD S. 2011 - La parure: traceur de la géographie culturelle et des dynamiques de peuplement au passage Mésolithique-Néolithique en Europe. Bordeaux : Université Bordeaux 1. Thèse de doctorat. .

ROCHE J. 1963 - L'Épipaléolithique marocain, Lisbonne : Librairie Bertrand.

ROGER J. 1942 - Note préliminaire sur le Sahélien. Les Invertébrés de la macro faune sahélienne d'Oran. Bulletin du Muséum National d'Histoire Naturelle, Paris, 14, p. 465-470.

RUSSELL N., BONSALL C., SUTHERLAND D. 1995. The exploitation of marine molluscs in the Mesolithic of western Scotland: evidence from Ulva Cave, Inner Hebrides. In: A. Fischer (Ed.), Man and Sea in The Mesolithic. Oxford: Oxbow Book, p. 273-288.

SACCO F. 1890-1904 - I Molluschi dei terreni terziari del Piemonte et della Liguria. Torin : Stamperia Beal.

SARI L. 2008 - Production lamellaire en contexte ibéromaurusien : variabilité et implication techno-économique. Cas du niveau inférieur de Rassel (littoral ouest algérois). In : H. Aouraghe, H. Haddoumi, K. El Hammouti, A. Oujda (Ed.), Le Quaternaire Marocain Dans Son Contexte Méditerranéen. Actes des quatrièmes rencontres des Quaternaristes marocaines (RQM4), Oujda (novembre 2007), Oujda, Publication de la Faculté des Sciences, Université Mohammed $1^{\mathrm{er}}$, p. 376388.

SARI L. 2012 - L'Ibéromaurusien, culture du Paléolithique supérieur tardif : approche technologique des productions lithiques taillées de Tamar Hat, Rassel et Columnata (Algérie). Paris : Paris 10. Thèse de doctorat.

SARI L. 2014 - Technological change in Iberomaurusian culture: The case of Tamar Hat, Rassel and Columnata lithic assemblages (Algeria). Quaternary International, 320, p. 131-142. 
SAXON E.C., CLOSE A., CLUZEL C., MORSE V., SHACKELTON N.J. 1974 - Results of recent investigations at Tamar Hat, Libyca, 22, p. 49-91.

SELLA G., ROBOTTI C.A., BIGLIONE V. 1993 - Genetic divergence among three sympatric species of Mediterranean Patella (Archaeogastropoda). Marine Biology, 115, p. 401-405.

SIDI MAAMAR H. 1987 - Étude de la faune malacologique de l'abri Alain, Oran, Algérie: Réflexion autour d'une escargotière ibéromaurusienne. Paris : Université de Paris I. Mémoire de maîtrise.

STEELE T., E. ALVAREZ-FERNANDEZ E. 2011 - Initial Investigations into the Exploitation of Coastal Resources in North Africa During the Late Pleistocene at Grotte des Contrebandiers, Morocco. In : N. F. Bicho, J.A. Haws, L.A. Davis (Ed.), Trekking the Shore: Changing Coastlines and the Antiquity of Coastal Settlement, New York : Springer, p. 383-403.

STEELE T. et ALVAREZ-FERNANDEZ E. 2012 - Restes de Mollusques marins. In : A. M. El Hajraoui, R. Nespoulet, A. Debénath, H. L. Dibble H.L. (Ed.), La Préhistoire de La Région de Rabat-Témara. Rabat: Villes et sites Archéologiques du Maroc, Vol. III, Rabat : Edition du Ministère de la Culture et de l'Institut National des Sciences de l'Archéologie et du Patrimoine, p. 223-227.

STINER M.C. 1999 - Trends in Paleolithic mollusk exploitation at Riparo Mochi (Balzi Rossi, Italy): food and ornaments from the Aurignacian through Epigravettian. Antiquity, 73, p. 735-754.

STINER M.C. 2003 - Standardization" in Upper Paleolithic Ornaments at the Coastal Sites of Riparo Mochi and Üçagizli Cave. In : J. Zilhão, F. d'Errico (Ed.), The Chronology of the Aurignacian and of the Transitional Technocomplexes: Dating, Stratigraphies, Cultural Implications, Lisbon :

Trabalhos de Arqueologia. p. 49-59.

SHINER M.C. et MUNRO N.D. 2011 - On the evolution of diet and landscape during the Upper Paleolithic through Mesolithic at Franchthi Cave (Peloponnese, Greece). Journal of Human Evolution, 60, p. 618-636.

STINER M.C., PEHLEVAN C., SAGIR M. et OZER I. 2002 - Zooarchaeological studies at Uçagizli Cave: Preliminary results on Palaeolithic subsistence and shell ornaments. Arkeometri Sonuslari Toplantisi. Ankara, 17, p. 29-36.

STOETZEL E., CAMPMAS E., MICHEL P., BOUGARIANE B., OUCHAOU B., AMANI F., EL HAJRAOUI M.A. et NESPOULET R. 2014 - Context of modern human occupations in North Africa: Contribution of the Témara caves data. Quaternary International, 320, p. 143-161.

TAYLOR V.K., BARTON R.N.E., BELL M., BOUZOUGGAR A., COLLCUTT S., BLACK S., HOGUE J.T. 2011 - The Epipalaeolithic (Iberomaurusian) at Grotte des Pigeons (Taforalt), Morocco: A preliminary study of the land Mollusca. Quaternary International, 244, p. 5-14.

TIXIER J. 1963 - Typologie de l'Epipaléolithique du Maghreb. Paris : Arts et métiers graphiques.

VANHAEREN M., D'ERRICO F., STRINGER C., JAMES S., L., TODD J. et MIENIS H. 2006 - Middle Paleolithic Shell Beads in Israel and Algeria. Science, 312, p. 1785-1788.

ZILHÃO J., ANGELUCCI D.E., BADAL-GARCIA E., D’ERRICO F., DANIEL F., DAYET L., DOUKA K., HIGHAM T.F.G., MARTINEZ-SANCHEZ M.J., MONTES-BERNARDEZ R., MURCIA-MASCAROS S. PEREZ-SIRVENT C., ROLDAN-GARCIA C., VANHAEREN M., VILLAVERDE V., WOOD R., ZAPATA J. 2010 - Symbolic use of marine shells and mineral pigments by Iberian Neandertals. Proceeding of National Academic Sciences of United States of America, 107, p. 1023-1028.

ZOUGHLAMI J., HARBI-RIAHI M., GRAGUEB A. et CAMPS G. 1985 - Atlas Préhistorique de la Tunisie 23 Gabès, Rome : École française de Rome. 


\section{ABSTRACTS}

Research on the Iberomaurusian has significantly increased in recent years, resulting in a better overall understanding of this period. However, studies focusing on human-animal relationships are still rare, especially for the exploitation of marine resources, which is paradoxical as most of the sites are located in coastal areas. In this work, we re-evaluate the marine malacofauna from the 1930s excavation of the Abri Alain rock shelter (Oran, Algeria), currently located five kilometers from the Mediterranean shore. The results obtained record the exploitation of marine resources by recent Iberomaurusian populations ( $15 \mathrm{ka}$ cal. BP). This malacofauna was used for subsistence but also as ornamentation. The consumed molluscs (Patellidae, Mytilidae, Trochidae) are characteristic of the intertidal zone of rocky shores. These species were probably gathered during low tides. Shells used as ornamentation (Dentaliidae, Glycymerididae, Cardiidae, Turritellidae) were originated from secondary locations.

INDEX

Keywords: Iberomaurusian, North Africa, Algeria, Marine malacofauna, Subsistence, Ornaments

\section{AUTHORS}

\section{EMILIE CAMPMAS}

UMR 5608 TRACES du CNRS, Université Toulouse Jean Jaurès, France - em.campmas@gmail.com

\section{AMEL CHAKROUN}

Université de Tunis El Manar, Faculté des Sciences de Tunis, Département de Géologie, El Manar, Tunisie

SOUHILA MERZOUG

CNRPAH, Alger, Algérie 